\title{
Article
}

\section{Every Student Counts: Promoting Numeracy and Enhancing Employability}

Tariq, Vicki and Waldock (editor), J

Available at http://clok.uclan.ac.uk/5346/

Tariq, Vicki and Waldock (editor), J (2011) Every Student Counts: Promoting Numeracy and Enhancing Employability. Devloping Graduate Skills in HE Mathematics Programmes - Case Studies of Successful Practice . pp. 40-41.

It is advisable to refer to the publisher's version if you intend to cite from the work.

For more information about UCLan's research in this area go to

http://www.uclan.ac.uk/researchgroups/ and search for < name of research Group>.

For information about Research generally at UCLan please go to http://www.uclan.ac.uk/research/

All outputs in CLoK are protected by Intellectual Property Rights law, including Copyright law. Copyright, IPR and Moral Rights for the works on this site are retained by the individual authors and/or other copyright owners. Terms and conditions for use of this material are defined in the policies page.

\section{CLoK}

Central Lancashire online Knowledge www.clok.uclan.ac.uk

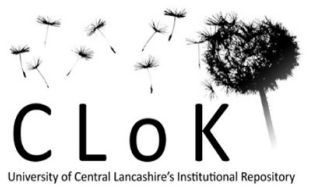




\section{Developing Graduate Skills in HE Mathematics Programmes \\ - Case Studies of Successful Practice \\ Edited by Jeff Waldock}



Developing Graduate Skills in HE Mathematics Programmes

- Case Studies of Successful Practice

Edited by Jeff Waldock

March 20ly 


\section{Acknowledgements}

This project was commissioned from the Mathematical Sciences HE Curriculum Innovation Project as part of the National HE STEM Programme.

Thanks are due to all case study authors for their contributions. Thanks are also due to members of the MSOR Network 'Graduate Skills and Employability Working Group' who attended the meeting 'Embedding Graduate Skills in UG Maths Programmes' funded by the Embedding, Enhancing and Integrating Employability (e3i) CETL at Sheffield Hallam University on 11 March, 2010, and to attendees at the workshop 'Embedding Graduate Skills in Your Mathematical Sciences Programme' which took place at Sheffield Hallam University as part of this project on November 24, 2010. Discussions between those attending these events have played a major part in forming this document. I would therefore specifically like to acknowledge the contributions of Edmund Chadwick, Neil Challis, Kevin Golden, Stephen Hibberd, Alison Hooper, Kevin Houston, Hazel Kendrick, Richard Lynch, Mary McAlinden, Guy Roberts, Mike Robinson, Peter Rowlett, Mike Thomlinson, Adrian Toland, Sidney Tyrrell, Erica Tyson and Louise Walker.

In addition, I would like to thank Chantal Jackson, of the University of Birmingham, for her excellent work in typesetting the material at short notice. 


\section{Background}

All stakeholders in Higher Education are increasingly aware of the importance attached to the additional skills students should be gaining at University, over and above their course-specific skills. Students are concerned, particularly with the large rises in tuition fees imminent, that courses will provide them with the full range of skills necessary to successfully gain graduate level employment. It is clear from University open days that prospective applicants are very aware of the new measures by which they can judge the performance both of Universities and of individual programmes, such as the National Student Survey, the Destination for Leavers from Higher Education survey of graduate employment and the various league tables, as published for example by the Guardian and the Times.

By August 2012, HEFCE expects all universities to publish Key Information Sets for each of their courses on their institutional website, 'providing prospective students with information about the HE experience that we know they find useful, in places we know they look for it’1. The KIS data will include student satisfaction metrics, learning and teaching activities and assessment methods, study hours, course accreditation, accommodation costs and graduate employment and salary outcomes.

In what is certain to be a very competitive student recruitment 'marketplace' there will be considerable importance attached by each university and by each course to presenting a successful profile by each of these measures. This is especially true at a time of high levels of graduate unemployment. The Guardian, for example, recently reported that '20\% of recent graduates are unemployed - the highest proportion for a decade"2 and 'Almost half of all recent graduates believe their university education did not adequately equip them for the world of work'3
In recent times, each of the relevant stakeholder groups has expressed views in support of these principles:

The Government (through the reports 'Higher Ambitions', and 'Unleashing Aspiration'):

'All universities should be expected to demonstrate how their institution prepares its students for employment, including through training in modern workplace skills such as team working, business awareness, and communication skills'

'Universities should develop proposals to integrate a flexible element of professional experience into all higher education courses'

This applies to postgraduate courses as well as undergraduate courses (Smith Report, 'One Step Beyond'. March 2010).

The student body (National Student Forum Annual Report, 2009):

'[Universities should] increase resources for, and promote the use of, personal development plans, and provide optional modules/classes that consider how the skills and knowledge are developed'

'We would like ... a clear university-wide employability strategy'

'We would like ... a high quality, well-structured work experience programme'

Employers (e.g. 'A Manifesto for Graduate Recruitment'). The importance of work experience - especially a placement year - is also highlighted:

'A third of graduate vacancies this year will be filled by applicants who have already worked for their new employer as an undergraduate'4

\footnotetext{
${ }^{1}$ HEFCE: http://bit.ly/eZ70Ab

Guardian, 26th January 2011: http://bit.ly/i492Vs

3Guardian, 28th January 2011: http://bit.ly/epsLiK

${ }^{4}$ Guardian, 18th January 2011. http://bit.ly/gX7MMj
} 
One immediate outcome has been the requirement from HEFCE that by August 31st 2010, all universities should publish an employability statement. This is described as 'a short summary of what universities and colleges offer to their students to support their employability and their transition into employment and beyond' and is intended 'to help prospective students make informed choices for entry in 2011-12'5.

In addition, the HE Mathematics community has implicitly identified the importance of the skills element of the curriculum through the National Benchmark Statement. It often comes as a surprise to potential applicants - when it is mentioned during, for example, an open day presentation - that there is no HE equivalent to the National Curriculum. The national benchmark statement does however 'represent general expectations about standards for the award of qualifications at a given level in terms of the attributes and capabilities that those possessing qualifications should have demonstrated"6. Reflecting the diversity of provision to be found across the UK in the discipline, it says very little about subject content, only explicitly referring to calculus and linear algebra. General skill development, however, is prominent:

'MSOR graduates will possess general study skills, particularly including the ability to learn independently, using a variety of media that might include books, learned journals, the internet and so on.

They will also be able to work independently with patience and persistence, pursuing the solution of a problem to its conclusion. They will have had the opportunity to develop general skills of time management and organisation. They will be adaptable, in particular displaying readiness to address new problems from new areas. They will be able to transfer knowledge from one context to another, to assess problems logically and to approach them analytically.

They will have highly developed skills of numeracy, including being thoroughly comfortable with numerate concepts and arguments in all stages of work. They will typically have general IT skills, such as word processing, the ability to use the internet and the ability to obtain information, always exercising these skills in a responsible way and taking care that sources are referred to appropriately.

They will also have general communication skills, typically including the ability to work in teams, to contribute to discussions, to write coherently and to communicate results clearly.
Where appropriate, they will have knowledge of ethical issues, including the need for sensitivity in handling data of a personal nature. All of these competencies enhance the general employability of MSOR graduates; see paragraphs 1.24 to 1.27.'

This of course raises the question - to what extent does the current curriculum in MSOR disciplines (and the Learning, teaching and assessment strategies that deliver, support and assess it) incorporate these principles - and where it does, how successful is it? There is no objective measure of this, but a subjective measure comes from the National Student Survey, one section of which addresses the area of personal skills.

Over the last three years (2008-2010), the position of Mathematical Sciences, as a discipline, can be ranked for each of these three questions against the subjects listed at Levels 2 and 3 in the raw data returns from the survey, available at http://www.unistats.com and http://www.hefce.ac.uk/learning/nss/data/2010/. The results are given in the following tables, where the number in brackets after the year indicates the number of universities included in the average. Full details at https://maths.shu.ac.uk/NSS/skills2.php.

\begin{tabular}{|c|c|c|c|}
\hline $\begin{array}{l}\text { National Student } \\
\text { Survey Question }\end{array}$ & $\begin{array}{c}2008 \\
(52)\end{array}$ & $\begin{array}{c}2009 \\
(62)\end{array}$ & $\begin{array}{c}2010 \\
(63)\end{array}$ \\
\hline $\begin{array}{l}\text { Q19: The course has } \\
\text { helped me present myself } \\
\text { with confidence }\end{array}$ & $\begin{array}{l}66 \% \\
42 \text { nd }\end{array}$ & $\begin{array}{l}66 \% \\
42 \text { nd }\end{array}$ & $\begin{array}{l}70 \% \\
42 n d\end{array}$ \\
\hline $\begin{array}{l}\text { Q20: My communication } \\
\text { skills have improved. }\end{array}$ & $\begin{array}{l}66 \% \\
42 \text { nd }\end{array}$ & $\begin{array}{l}65 \% \\
42 \text { nd }\end{array}$ & $\begin{array}{l}70 \% \\
42 n d\end{array}$ \\
\hline $\begin{array}{l}\text { Q21: As a result of the } \\
\text { course, I feel confident in } \\
\text { tackling unfamiliar problems. }\end{array}$ & $\begin{array}{l}75 \% \\
30 \text { th }\end{array}$ & $\begin{array}{l}77 \% \\
28 \text { th }\end{array}$ & $\begin{array}{l}77 \% \\
28 t h\end{array}$ \\
\hline
\end{tabular}

\section{Table 1}

Data for 'Mathematical Sciences' from the National Student Survey, Questions 19-21, averaged across all institutions reporting, and its rank within the $\mathbf{4 2}$ Level 2 subjects.

${ }^{5}$ HEFCE circular letter, 10 June 2010, http://www.hefce.ac.uk/pubs/circlets/2010/cl12_10/ ${ }^{6} \mathrm{QAA}$ Benchmark statement for Mathematics, Statistics and Operational Research, http://bit.ly/ewzwEJ 


\begin{tabular}{|l|c|c|c|}
\hline $\begin{array}{l}\text { National Student } \\
\text { Survey Question }\end{array}$ & $\begin{array}{c}\mathbf{2 0 0 8} \\
(50)\end{array}$ & $\begin{array}{c}\mathbf{2 0 0 9} \\
(61)\end{array}$ & $\begin{array}{c}\mathbf{2 0 1 0} \\
(63)\end{array}$ \\
\hline $\begin{array}{l}\text { Q19: The course has } \\
\text { helped me present myself } \\
\text { with confidence }\end{array}$ & $\begin{array}{c}65 \% \\
101 s t\end{array}$ & $\begin{array}{c}66 \% \\
103 r d\end{array}$ & $\begin{array}{c}70 \% \\
101 s t\end{array}$ \\
\hline $\begin{array}{l}\text { Q20: My communication } \\
\text { skills have improved. }\end{array}$ & $\begin{array}{c}65 \% \\
103 r d\end{array}$ & $\begin{array}{c}64 \% \\
104 t h\end{array}$ & $\begin{array}{c}70 \% \\
106 \text { th }\end{array}$ \\
\hline $\begin{array}{l}\text { Q21: As a result of the } \\
\text { course, I feel confident in } \\
\text { tackling unfamiliar problems. }\end{array}$ & $\begin{array}{c}75 \% \\
74 \text { th }\end{array}$ & $\begin{array}{c}76 \% \\
72 \text { nd }\end{array}$ & $\begin{array}{c}77 \% \\
70 \text { th }\end{array}$ \\
\hline
\end{tabular}

\section{Table 2}

Data for 'Mathematics and Statistics' from the National Student Survey, Questions 19-21, averaged across all institutions reporting, and its rank within the 106 Level 3 subjects.

These data clearly suggest that students studying Mathematics perceive a problem in terms of their development of personal skills - at least, in relation to their own expectations. Given the consistency in this pattern over the last three years, it appears that there is a need to tackle the issue. Should we as a community be supporting each other in developing new approaches to skill development within Mathematics programmes, and if so, how?

\section{Approaches taken to embedding graduate skill development}

There are significant barriers involved when seeking to modify Mathematics programmes to encourage the development of graduate skills. One is fundamentally philosophical, as some will wish to retain the pure, theoretical nature of their courses. Another is the practical difficulty of finding space for graduate skill development in a crowded curriculum.

This latter problem can be addressed - at least in part - through different approaches toward learning, teaching and assessment that allow skill development to take place alongside the development of the mathematical skills, and by encouraging students to take part in extra-curricular activities. Central to this is the need to increase student awareness of the wider purpose of each activity in developing their skills, and the value of doing so. In this regard, it is very important that students are able to recognise the part each activity plays in helping them towards the attributes expected of a graduate from their course. If so, they will be better able to see the benefit of the curricular strategies adopted, and hence better able to articulate their skill development when required.
The introduction of the Higher Education Achievement Record, as recommended by the Burgess Report, will provide further incentive for this.

This booklet presents a series of short case studies, each focussed on specific graduate skills, providing examples of ways in which these have been successfully developed through curricular initiatives. There is a wide variety of work reported, both in terms of the skills developed as well as the type of courses and institutions involved. The hope and expectation is therefore, that there will be something of interest and relevance to everyone who has a desire to make curricular changes aimed at improving the 'graduate' skill levels of their students.

The requirement by HEFCE to publish employability statements has forced universities to articulate clearly exactly what it is they are providing students with in this regard, and to highlight the ways in which individual courses help students both to develop employability skills, and to recognise their importance. One approach categorises these skills, identifying the activities within the curriculum that are involved. Course planners can then map these activities, showing progressive skill development across each level, and students can see how each activity is designed to build their skill set towards that expected of a graduate.

It is often the case that courses already include such activities, building employability skills alongside subject-specific technical skills, but without emphasising the fact. A light touch modification of a course, pulling together a 'skills map' to raise awareness of this may prove effective in itself. A fuller map, such as the one illustrated in Appendix 3, taken from Case Study 8 (Sheffield Hallam), may be used to identify a thread of employability activities throughout a course. A similar approach has been adopted at the University of the West of England (Case Study 11), through their Graduate Development Programme.

One convenient skills categorisation, reflecting the key areas identified as 'graduate skills' applies the following groupings:

1. Work-based learning and/or work-related learning

2. Reflection and action-planning, including Personal Development Planning (PDP) and work portfolios

3. Career Management Skills (CMS)

4. Employability skills (those not covered above, such as skills in team working, communication, leadership, autonomy and self-awareness) 


\begin{tabular}{|c|c|c|c|c|}
\hline \multirow{2}{*}{ Case Study } & \multicolumn{4}{|c|}{ Skill Group } \\
\hline & 1 & 2 & 3 & 4 \\
\hline 1: Calculating Careers & & & $\mathrm{Y}$ & \\
\hline 2: Personal Development Planning & & Y & & \\
\hline 3: Professional and Graduate Skill Modules & & Y & Y & Y \\
\hline 4: Integrative Use of Group Projects & & & & $\mathrm{Y}$ \\
\hline 5: Venture Matrix & $\mathrm{Y}$ & & & $\mathrm{Y}$ \\
\hline 6: Peer Assisted Learning & & & & Y \\
\hline 7: Progress Files & & Y & & $\mathrm{Y}$ \\
\hline 8: LTA Approaches to Employability & & Y & & Y \\
\hline 9: Placement Preparation & & & $\mathrm{Y}$ & \\
\hline 10: Art Gallery Problems & & & & Y \\
\hline 11: Graduate Skills Development Programme (GDP) & & $\mathrm{Y}$ & Y & $\mathrm{Y}$ \\
\hline 12: Writing and Thinking & & & & $\mathrm{Y}$ \\
\hline 13: Developing Models Applied to Business and Industry & Y & Y & & Y \\
\hline 14: Case Study Booklets on Basic Mathematics & & & & $\mathrm{Y}$ \\
\hline 15: Every Student Counts & & & & Y \\
\hline 16: Business Applications of Mathematics & $\mathrm{Y}$ & & & $\mathrm{Y}$ \\
\hline 17: Embedding Careers Awareness & & & $\mathrm{Y}$ & $\mathrm{Y}$ \\
\hline
\end{tabular}

\section{Table 3}

Categorising the skills developed by the present set of case studies

More detail of these is provided in Appendix 1. Table 3 below provides a summary of these skill groups, as addressed by the set of case studies presented in this report.

It is very noticeable that nearly all - 14 of 17 - address generic employability skills, particularly communication and team working, reflecting the importance attached to these skills, and if allowance is made for the fact that career planning and PDP include elements such as self-awareness, the coverage is $100 \%$.

The development of Career Management Skills (CMS) is the second most commonly addressed skill group, reflecting perhaps the increased desire both to raise students' awareness of the potential career paths they may follow, and the practical skills necessary to succeed in them. It is noticeable that nearly all of the case studies that deliver CMS do so throughout the programme, recognising that it takes time to build these skills to an appropriate level and that on its own an 'outduction' programme preparing students for transition to the world of work, while important, is not enough. It is also the most likely to be carried out through a separate, possibly ex-curricular, bolt-on delivery model and taught by non-mathematicians. It is important for mathematics students to understand their potential job market, however, and the development of CMS skills should take this into account. As with other employability skill development, this is therefore more likely to be successful if it takes place within the mathematics curriculum.

Relatively few of the case studies address the other two groups of skills. Reflection and action-planning, or PDP, is often seen as a completely separate activity from the core curriculum and consequently marginalised, being carried out infrequently, often under duress. An alternative approach starts with the view that in order to maximise achievement, it is important for a student to raise their levels of selfawareness, identifying their strengths and weaknesses and having the capacity to develop a plan of action for addressing the latter. This way, the PDP process can be seen as supportive and beneficial and, provided that it is managed effectively by staff and carried out on a regular basis, can be very effective.

Work experience, as mentioned earlier, can make a significant difference to a student's chances of gaining graduate level employment. If graduate employability is of importance to course designers, it seems clear that the curriculum should embrace some form of work-based, or work-related, learning. There are a number of models to follow - and not all require a full sandwich year. There is clearly much to be gained 
from helping students recognise, and articulate, the skills they gain from all forms of work, including voluntary and casual work. Many universities now operate a skills award which recognises this, but it is possible for the course curriculum to also incorporate explicit recognition of the skills acquired in the workplace, wherever that may be.

With the introduction of the Higher Education Achievement Report (HEAR) in 2011-12, as recommended by the Burgess Report ${ }^{7}$, it is expected that a much fuller description of all student achievement will be recorded, including wider verified achievements that will appear in section 6.1. All universities will need a system that can provide a verified record of relevant student achievements. Employability skills, assessed through the curriculum, could certainly form an important element of section 6.1 of the HEAR.

One final thought is that many of the case studies reported here emphasise that one vital element in success is that students perceive the activities, and the skills developed though engagement with them, as valuable. Obvious though it may be, it is worth remembering that much progress can be made by including students as equal partners in the learning process, and their input and feedback will improve the effectiveness of each initiative.

The project was commissioned from the National HE STEM Programme Mathematical Sciences Strand through the MSOR Network.

For more information, go to http://maths.shu.ac.uk/msor/graduateskills/.

Please consider adding your own case study to the online collection by downloading the template and emailing it to: j.waldock@shu.ac.uk.

Jeff Waldock, Department of Engineering and Mathematics, Sheffield Hallam University.

March, 2011

7"Beyond the Honours Degree Classification", Universities UK, 2007. http://bit.ly/fOHNXO 
Developing Graduate Skills in HE Mathematics Programmes - Case Studies of Successful Practice 
Skill

Autonomy

Career planning and management

Commercial awareness

Developing mathematical models

Emotional Intelligence

Employment awareness

Initiative, enterprise

LaTeX and Office skills

Leadership

Logical analysis/thinking

Numeracy

Personal/action planning

Presentation skills

Problem-solving

Referencing

Self awareness, reflection

Subject-specific skills

Team-working, networking and Interpersonal skills

Time management and organisation

Verbal communication

Written communication
Case Study

6,8

$1,3,9,11,17$

1

$4,10,13$

14,16

9,11

5

3

5,6
14,15

$1,2,7,13$

$3,6,10,11,12,13,16$ $4,10,13,14,16$

$2,3,7,8,11,13$

$4,10,12,13,14$

$1,3,4,5,6,10,11,13,16$

$1,8,13$

$2,4,6,10,11,13,16$

$2,4,7,10,11,12,13,16$ 
1 Calculating Careers, Louise Walker, University of Manchester

Commercial awareness $\bullet$ Networking $\bullet$ Planning and Organisation $\bullet$ Career Management

2 Personal Development Planning, Mary McAlinden, Oxford Brookes University

Reflection • Self-Awareness • Action-Planning • Communication

3 Professional and Graduate Skills Modules, Sidney Tyrrell, Coventry University

Group work $\bullet$ Presentation skills $\bullet$ Reflection $\bullet$ LaTeX and Office skills

4 Integrative use of Group Projects, Stephen Hibberd, University of Nottingham

Subject-specific • Problem solving • Team-working • Communication

5 Venture Matrix, Jeff Waldock, Sheffield Hallam University Leadership • Teamwork • Enterprise • Entrepreneurship

6 Peer-Assisted Learning, Jeff Waldock, Sheffield Hallam University Teamwork $\bullet$ Autonomy $\bullet$ Leadership $\bullet$ Communication $\bullet$ Presentation skills

7 Progress Files, Jeff Waldock, Sheffield Hallam University

Reflection • Action-planning $\bullet$ Communication

8 LTA Approaches to Employability, Jeff Waldock, Sheffield Hallam University

Self-awareness • Self-organisation • Autonomy

9 Placement preparation, Jeff Waldock, Sheffield Hallam University

Career management $\bullet$ Interview preparation $\bullet \mathrm{CV}$ development

10 Using Art Gallery Problems to Develop Mathematical and Employability Skills in a Higher Education Group Project, Peter Rowlett, Nottingham Trent University Identifying assumptions in mathematical arguments • Referencing • Communicating using reports and presentations • Team working

11 Graduate "skills" Development Programme (GDP), Kevin Golden and Guy Roberts,University of the West of England

Reflection • Teamwork • Communication • Presentation skills • Employment awareness 
12 Writing and Thinking, Kevin Houston, University of Leeds

Written/visual communication and presentation • Logical thinking • Subject-specific

13 Student teams developing mathematical models applied to business and industrial mathematics, Edmund Chadwick, University of Salford

Developing mathematical models • Problem solving • Group work • Presentation skills •

Organisation • Action-planning • Communication • Reflection.

14 A Series of 12 Case Study Booklets on Basic Mathematics, Peter Samuels, Gareth Williams and David Bowers, University of Coventry, Birmingham City University and University Campus Suffolk

Developing skills in numeracy, proof, mathematical writing, assessment, algebra, emotions, problem solving and statistics.

15 Every Student Counts: Promoting Numeracy and Enhancing Employability teams,

Vicki Tariq, University of Central Lancashire

Numeracy skills

16 Business Applications of Mathematics,

Valerie Matthews-Lane, Clive Rix and Richard Mendez, University of Leicester

Problem solving • Communication \& interpersonal skills •

Team working • Oral and written presentation techniques.

17 Embedding careers awareness in the first two years of a Mathematics degree,

David Graham and Annette Millar, University of Plymouth

Careers awareness $\bullet$ Writing job applications $\bullet$ Compiling CVs

Appendix 1: A Classification of Graduate Skills

Appendix 2: Mechanisms and Inputs for Embedding Graduate Skills

Appendix 3: An Employability 'Thread'

Appendix 4: A Typology of Modes of Work-Based Learning

References and web links 


\title{
l: Calculating Careers
}

\author{
Skills Addressed:
}

Commercial awareness • Networking • Planning and organisation

\section{Louise Walker}

School of Mathematics, University of Manchester

\section{Context}

The Careers Service at the University of Manchester has long been recognised as one of best in the country, voted top careers service for five consecutive years by the Association of Graduate Recruiters [1]. However too many of our students leave their career planning until late in their programme or after graduation. To encourage our students to engage with the Careers Service earlier and to make sure they are aware of the range of careers open to maths graduates we have initiated a series of maths dedicated career events called 'Calculating Careers' based in the School of Mathematics.

In September 2009 we asked our new mathematics undergraduates whether they had a specific career in mind when they graduate. Out of the 296 responses, 197 (67\%) answered 'no'. Of course, at this stage in their education this need not be a cause for concern and in fact one of the attractions of studying a mathematics degree is that it leaves career options fairly open. However the results highlight the fact that our students need effective support and advice throughout their programme to help them to find rewarding and interesting careers when they graduate.

One of the main messages to convey is that, when it comes to career planning, it pays to start early. In the first year, we should help students to develop their CVs and find out about their career options.
There are opportunities for gaining useful experience such as the spring weeks offered by many of the large financial institutions.

During their second year, students should be encouraged to apply for internships and other work experience. Employers are increasingly using internships as a recruitment tool and even if a student is not offered a job with the same company, the experience will strengthen their $\mathrm{CV}$. Internships are competitive but, even if unsuccessful, a student will benefit from the experience of filling in application forms and focusing on their strengths and weaknesses.

Applications to graduate employment schemes start early and students need to be well-prepared by the start of their final year. However students should be aware that there are other options available, not just with large companies. Small and medium sized enterprises will consider students with 2:2 or 3rd class degrees if they have other qualities and skills to offer.

\section{Implementation (including barriers and enablers)}

To help our students with career management we have instigated a series of maths specific careers events under the banner 'Calculating Careers'. The main annual event is a Careers Fair for mathematics undergraduates and postgraduates held in the 
School of Mathematics. This has run in October 2008 and 2009 and has attracted over 20 graduate employers and over 250 students each year. The employers included banks, actuarial and insurance firms, the civil service, engineering, energy and retail companies. They were selected as known recruiters of mathematics graduates and many have offices in Manchester or the North West. Several of the representatives on the company stands were recent graduates from the School. As well as a chance to talk to company representatives, there were themed panel sessions where students could question experts about careers in finance, technology and teaching. Careers advisors were on hand to give practical advice on CVs and applications.

Before the fairs we ran information sessions to help students prepare for the event, and a detailed brochure with employer profiles and advice on how to make the most of the event was circulated. Throughout the academic year we run follow up events such as applications and CV workshops, talks on teaching mathematics and careers for statisticians and visits to the School by employers and training agencies. A recent event for final year students gave advice on what to do after graduating such as the Manchester Graduate Internship Programme and other graduate recruitment events [2].

The School has developed a Careers Wiki [3] with specific information for maths students, including profiles of graduate employers, examples of careers, careers events of interest to our students and general advice on job hunting, applications and CVs, online tests and assessment centres, interviews and internships. Recent graduates from the School write about their job hunting experiences and career choices.

To complement the Calculating Careers activities we have written an Employability Skills guide. This gives practical advice on developing skills by choosing particular course options and participating in useful extra-curricular activities. The guide has a suggested 'career timeline' so that students can plan their career management from the start of their programme. It also includes advice from a recent graduate on the skills and knowledge that they find useful in their current job as an Actuary.

The challenge is to make sure that all our students are actively engaging in planning their career or further study after graduating. We intend to integrate career planning and skills development into our personal tutoring system. The employability guide will be used as a focus for review meetings between the students and their personal tutors in the coming academic year. A training and information session by the Careers Service is being organised for staff in the School to help personal tutors support their students' personal development. Academics should not be expected to offer careers advice but should know where to direct a student for help with career planning and skills development.

\section{Evidence and recommendations}

The interest from employers in our Calculating Careers events has been positive and we have had no difficulty finding representatives from a range of sectors. The 450 students attending the 2008 Fair were asked to fill in an evaluation form. Over $80 \%$ of the respondents were happy with the sectors represented and over 90\% thought it was worthwhile attending. The main reasons for attending were to seek careers advice and intern opportunities, with $43 \%$ of the respondents saying the employers represented had good graduate and intern opportunities. For $51 \%$ of the students, this was the first careers event they had attended. Holding a maths specific event in the School may have encouraged students to find out about careers at an earlier stage than they would have otherwise.

It is too early to tell whether our Calculating Careers initiative has made a difference to students' employability. The Destinations of Leavers from Higher Education [4] currently has information on employment gathered in November 2008. The survey asks graduates about their status six months and three and a half years after they graduate, in particular what percentage are in 'graduate' jobs. This information is listed on the Unistats website [5]. Of course, recent economic events have had a major effect on graduate recruitment and so this may cancel out any positive action. However anecdotal evidence suggests that our efforts have been greatly appreciated by our current students who need all the help they can get in a competitive jobs market.

\section{References/more information}

1. http://www.agr.org.uk/

2. http://www.careers.manchester.ac.uk/

3. http://www.maths.manchester.ac.uk/ bl/ careerswiki/Main/CalculatingCareers

4. http://www.hesa.ac.uk/index.php/content/ view/112/154/

5. http://unistats.direct.gov.uk/ 


\section{己: Personal Development Planning}

\section{Skills Addressed:}

Reflection • Self-awareness • Action-planning $\bullet$ Communication

\section{Mary McAlinden}

School of Technology, Oxford Brookes University

\section{Context}

The QAA Progress Files guidelines [1] define personal development planning (PDP) as: "a structured and supported process undertaken by an individual to reflect upon their own learning, performance and / or achievement and to plan for their personal, educational and career development". Students in HE may experience PDP in a variety of different ways. For example, they may meet it as an add-on to their academic studies and be given access to tools for recording their personal achievement which may be accompanied by other forms of support and advice. Alternatively, they may find it more closely integrated into their core course studies. In Mathematics, the explicit inclusion of PDP within the curriculum can encourage self-reflection and assist students to improve and develop their skills for employability in a structured way, at the same time as they are extending their knowledge and understanding of the subject.

\section{Implementation (including barriers and enablers)}

Since September 2005 a strand of PDP has been incorporated into a final year Mathematics module at Oxford Brookes University. [2] The module carries 30 credits, runs throughout the year and is on offer to all students on the specialist programmes in
Mathematics and Mathematical Sciences. The PDP strand of the module carries $10 \%$ of the total marks and has an allocated member of staff but has no dedicated timetabled teaching slot.

The key emphasis in the PDP strand of the module is on careers preparation and self awareness of transferable skills development. Students follow a structured PDP programme, the constituents of which have varied with experience in using the scheme and in response to student feedback. In the most recent run of the module the programme included seminars on CV preparation, interview techniques and library and information resources. Students were also required to give a presentation on a mathematical topic and share peer feedback in a small group setting. In addition, they undertook an action planning exercise, produced a log of how their transferable skills developed during the academic year and had to write a series of short reflective statements.

Students submit two short PDP logbooks for assessment. The contents of these logbooks are specified in detail and a template is provided. This includes forms for providing evidence of attending the various sessions, grids for keeping records of feedback and skills development and space for writing reflective statements. All components of the PDP programme carry a small assessment weighting 
and are categorised broadly as either activities to be completed or reflective written work. Students are awarded full marks for completing an activity exactly as specified and their written work is graded using a published assessment matrix. The assessment scheme is designed in such a way that failure to participate in an activity will have a knock-on effect on the student's ability to write the corresponding reflective statement and hence result in a more substantial penalty.

Midway through the year, following the first assessment point, students receive formative feedback on their work via an interview. This provides scope for a one-to-one discussion of the student's career plans and their awareness of skills development. It also provides an excellent opportunity to challenge students to extend the domain of their skills and personal development beyond curriculum boundaries and openly encourages greater use of personal initiative. For this purpose the discussion of a student's prepared action plan can be an invaluable starting point.

The content and assessment of the PDP programme described differ substantially from what students expect in a Mathematics module. This is one of the challenges in implementing the programme. Students need to understand the relevance of their PDP work and a realistic amount of academic credit needs to be available to rewards their efforts. Experience suggests that this provides the initial incentive for engagement with the scheme and that a deeper understanding of its value evolves over time. For the programme to work effectively, in parallel with the mathematical content of the module, great care is needed to ensure that the assessment is kept to a manageable level for students.

From a staff perspective, one of the greatest barriers is in running the programme without a dedicated timetabled teaching slot. As the module includes students from a range of combined (or joint) honours degree programmes, significant scheduling difficulties can arise when attempting to arrange seminars outside class time.

\section{Evidence and recommendations}

An evaluation of the PDP programme takes place at the end of the module when students are asked to provide formal feedback on their experiences. Further insightful information can be gleaned from the work submitted for assessment purposes. From this collective feedback it can be established that the activities to which students respond most positively are those which they perceive as both relevant and timely. For example, a time-management exercise does not work well with third year students and preparation for interviews is most well received when it takes place in the run-up to an actual interview. It is therefore essential that student feedback is used to inform the development of the programme.

Experience has shown that it cannot be assumed that Mathematics students automatically understand what a piece of reflective writing entails. While written guidance certainly has its value, in many cases students require more assistance than this. One way in which this can be achieved is through the detailed structuring of the PDP programme. For example, requiring students to log their transferable skills development and then write a reflective statement about their skills can produce a much greater reflective response than when they only have to write the statement. Students also need to be able to ask questions about the process and more specifically about how it applies to them as individuals. The involvement of a dedicated member of staff is therefore crucial.

Some students have identified that one of the benefits of PDP is the requirement to think more about careers. Explicitly including PDP in a module provides a structured framework for directing students to focus on this area. It can also assist them in acquiring greater self awareness and actively encourages the development of their skills for employability.

\section{References/more information}

1. McAlinden, M. (2007) 'A structured approach to incorporating personal development planning into a mathematics module'. In Green, D. ed. CETLMSOR Conference 2006 Conference Proceedings. The Maths Stats \& OR Network, Birmingham pp. 108-112

2. QAA (2001) "Progress Files for Higher Education". Accessed via http://www.qaa.ac.uk/ academicinfrastructure/progressFiles/default.asp. (29 May 2010) 


\title{
3: Professional and Graduate Skills modules
}

\author{
Skills Addressed: \\ Group work • Presentation skills • Reflection • LaTeX and Office skills
}

\section{Sidney Tyrrell}

Department of Mathematics, Statistics and Engineering Science, Coventry University

\section{Context}

In 2006 Coventry University restructured the undergraduate curriculum framework to provide students with a choice of 150 compulsory half modules, Add+Vantage modules, each of which has embedded employability competency skills. This is complemented by a compulsory skills half module in the first and second year of all mathematics courses, with the passing of these modules a prerequisite for progression. Different members of the Department are involved with the teaching and all see the modules as an important part of our programmes.

\section{Implementation (including barriers and enablers)}

In the first year the compulsory half module of Academic and Professional Training is for all students on mathematically related courses, and is taught for 11 two hour sessions spread over two terms, in a room with PCs. The module leader has some commercial experience and the content covers

- Personal skills: Study skills, Reflection on individual learning needs, Time management.

- Career skills: writing a CV; creating a Personal Development Portfolio.

- Academic skills: Use of the Library portal and subject specific databases; Referencing.

- Professional skills: use of Microsoft Word, Outlook, Excel and PowerPoint, File management. Introduction to LaTeX

- Working effectively as a member of a group; written and oral presentations.

With the introduction of Activity Led Learning much of the teaching in the first half of this module revolves around the conduct of a small scale sample survey looking at the student experience of Induction week, or some other topic. This covers questionnaire design, sampling theory, collecting data from approximately 700 students from across all Faculties, analysing it in Excel, drawing effective charts and tables in Excel, and presenting the findings using PowerPoint. Teaching is focussed on each of these aspects, with time at PCs for students to put it in to practice for themselves using the data they had collected. Much of the student work is done in small groups which may change each week in the early part of the module.

Use is made of other professional staff from the Careers Service and the Library to deliver their specialist advice, and another member of the mathematics staff teaches LaTeX. Assessment is through an oral presentation (10\%); group work (25\%) analysing and presenting in PowerPoint the 
survey findings; and the presentation of an online personal development portfolio which includes evidence of each week's activities (65\%).

In the second year module we cover

- Academic Skills: library skills, referencing, use of SPSS,

- Professional skills: Project management, CPA, Gantt charts; written and oral presentations;

- Writing of a report to professional standards.

- Personal skills: Writing application letters and a $\mathrm{CV}$; researching placements;

- Maintenance of a Personal Development Portfolio showing reflection, self evaluation and evidence of personal development over the preceding year.

Again this is taught for 11 two hour sessions spread over two terms, using the same rooms as the first year module, which is a saving in timetabling. Use is made of other professional staff from the Careers Service and the Library to deliver their specialist advice. Assessment is by a written test in critical path analysis and Gantt charts (20\%), a written report (40\%) and a personal development portfolio (40\%), which included research on a possible placement, a letter of application, and a CV.

Despite the Department seeing these modules as an integral part of our courses, the biggest challenge is to get every student to take this type of work seriously, and to make it as relevant as possible to mathematics and the final year project as well as providing general employability skills. The many who did see its relevance particularly appreciated the work on CVs, on presentations and on learning LaTeX.

In the second year the most difficult topic to teach effectively is writing a good report, which this year was put into practice with reports on "Professional and Academic Skills". In both years the giving of timely and useful feedback on the portfolios is extremely time consuming and needs to be re-visted.

\section{Evidence and recommendations}

Evaluation forms are completed at the end of the modules, students being asked to comment on what they felt were the good and bad points of the scheme.

Specific responses include:

- "Built up my self confidence, and I am now more comfortable speaking in front of people"
- "a great opportunity to improve on my group working skills"

- "Effective learning",

- "Helps improve employability skills."

- "I feel this module has helped me develop skills and learn things that to be honest I didn't think I would learn at University, however I think these skills are useful."

Benefits for the students include:

- The opportunity at an early stage of their course to work in different small groups on practical activities, helping with social integration of the cohort across courses.

- Early access to professional staff from Careers and the Library service.

- Gradual acquiring of skills necessary for undertaking a project in the final year.

- As early a start as possible to thinking about a future job, and thinking about the skills that might be picked up at University, as well as a degree, to help achieve that aim.

Benefits for the University include:

- Producing students as well equipped as possible for life after a first degree. 


\title{
4: Integrative use of group projects in Mathematics
}

\author{
Skills Addressed: \\ Subject-specific • Problem solving • Team working • Communication
}

\section{Stephen Hibberd}

School of Mathematical Sciences, University of Nottingham

\section{Context}

Skills development within an HE degree is emerging as a high-priority area and explicit recognition of the importance of harmonising skills development within undergraduate degree programmes, as expected by QAA qualifications, include:

- apply the methods and techniques that they have learned to review, consolidate, extend and apply their knowledge and understanding, and to initiate and carry out projects;

- communicate information, ideas, problems and solutions to both specialist and non-specialist audiences.

- the qualities and transferable skills necessary for employment ...

Including extensive skill-based outcomes within traditional mathematics degrees remains a challenge that can be enabled by project-based activities and used to extend student understanding and their application of knowledge gained from traditional lecturebased methods. Wider use of group project activities can further provide significant pedagogic and efficiency advantages within wider skills development modules.

\section{Implementation (including barriers and enablers)}

Vocational Mathematics is a synoptic module available to third year Mathematics students bringing together the subject-specific knowledge and mathematical skills attained in initial years of a mathematics degree in tandem with developing the wider skills expected for graduate careers or higher degrees. Development workshops and group activities give students awareness and exposure to relevant skills; extended group projects promote attainment of a wide range of skills. Skills addressed include organisation and delegation, project management, team working, together with more subject-specific skills of addressing more substantial unseen problems and open-ended analysis to demanding deadlines. Tasks require background research, selecting and applying mathematical techniques to obtain results and integrating the use of mathematical and presentational software for ultimately communicating quantitative ideas orally and in compact reports. Students experience an emphasis on:

- working collectively in a non-lecture environment;

- problem solving with a variety of directions and approaches;

- applying previously acquired mathematical techniques and their communication;

- experiencing first-hand applications of team skills.

Pedagogic advantages include

- students can learn from each other; 
- group project activities increases the scope of projects and outcomes to a high level;

- students experience teamwork on a substantial level, self/peer evaluation and detailed feedback.

Group and Team skills: Experiencing the requirement to deliver in a tight timeframe in unfamiliar tasks and recognition of different group approaches makes students more receptive to understanding the concepts of group skills. An awareness of characteristics of teams is crucial to its effectiveness. Members can contribute in drawing on their technical knowledge but also have a potentially valuable team-role to perform.

Graduate skills: We explore the rationale for employing graduates. What are the general attributes and specific skills expected by potential employers from (mathematics) graduates? In practice, the students are dealing with their perceptions and are generally unaware of the skills they attain from a Maths Programme.

Project skills: Importantly, the module is strongly rooted in mathematical modelling, i.e. how to apply mathematics and how to communicate findings. Elements of modelling are included within earlier core modules but 'Voc Maths' enables greater exploration of competing models or wider evaluation. Obtaining, assessing and researching relevant background information is an essential part of any study. During the module students will need to access a variety of information technology resources to help with mathematical computations and also to word-process project reports and to prepare and display materials for oral presentations. Training support for students is provided and student (group) presentations are videod for each project oral report and made available to student groups and used for feedback.

\section{Evidence and recommendations}

At the start of the module a detailed skill survey based on student's intake perception of skills is conducted and this is repeated at the end of module to give a profile of skills changes. These show generally an increase in perceived skills and also realisations to students of their own capabilities, strengths and weaknesses. Student feedback is excellent; a recent response highlighting our ideal:

"The best thing about this module is the skills that this module allows students to develop, many of which could not be developed in any other module. I feel that in terms of employability, this module had more value than any other course that I took; with report writing, teamwork and presentation skills being so key to so many careers and yet such a weak focus on these skills in any typical mathematics degree, I would say that any student would benefit from taking G13VOC. If this module was compulsory for all mathematicians, the quality of graduates would be greatly improved". Student feedback to School Evaluation of Modules (2010)

Project activities are widely identified as a valuable component of a mathematics degree programme but often restricted by concerns over implementation issues such as management, organisation and provision of project activities, training in skills, assessment, plagiarism, feedback, staffing, etc. Concerns seem intensified within group project activities, however the potential for enhancement of skills, peer learning and assessment are considerable together with greater efficiency on staff resources.

Vocational Mathematics was unique within the mathematics programme at Nottingham as entirely group-project based and assessed through group project activities. Support from the School and modest financial support from the University to help frame workshops and develop projects enabled the module to be initiated. The initial restricted target cohort is now extended as an optional all final year BSc students and an extended version of this module is available to some MSc programmes prior to an extensive dissertation.

\section{References/more information}

1. Quality Assurance Agency (2008). The Framework for Higher Education Qualifications in England, Wales and Northern Ireland. Available at http: //www.qaa.ac.uk/academicinfrastructure/FHEQ/ EWN108/default.asp

2. Hibberd, S. (2010) 'Maths, skills and employability - an integrative use of group projects'. In Robinson, M., Challis, N. \& Thomlinson, M. eds. Maths at University, 182-187. More Maths Grads project, Sheffield Hallam University.

3. Hibberd, S. (2010) 'Maths, skills and employability - an integrative use of group projects'. In Baker, G.,Falk-Whynes, J. \& Sidorovitch, A.. Teaching for Integrative Learning - Innovations in University Practice. Published by the Centre for Integrative Learning, Nottingham University. ISBN: 978-0-9563525-2-1

4. Hibberd, S. (2007) 'Harmonising learning and graduate skills in the mathematical sciences'. In Green, D. ed. CETL-MSOR Conference 2006 Conference Proceedings. The Maths Stats \& OR Network, Birmingham pp. 80-86. ISBN 978-0-9555914-0-2 


\section{5: Venture Matrix}

\section{Skills Addressed:}

Leadership • Teamwork • Enterprise • Entrepreneurship

\section{Jeff Waldock}

Engineering and Mathematics, Sheffield Hallam University

\section{Context}

The Venture Matrix (VM) is a University-wide learning scheme providing students with a chance to simulate the business world as an accredited part of their course. It is designed to encourage an entrepreneurial spirit, helping improve skills for employment.

The Venture Matrix extends the concept of enterprise education beyond the familiar tools of ghost companies and virtual business simulations by enabling students to form their own businesses, social enterprises and other ventures and to trade with each other in person in a safe, mentored environment. This helps them to gain realistic work experience and develop some important skills that they might otherwise find hard to gain in their programme of study.

The VM scheme was developed to address vocational education at HE level, particularly in response to governmental policy of widening participation, the emergence of enterprise education as an integral part of the curriculum, and the role of employers in HE.

Since students from each level and from a variety of courses are involved in the Venture Matrix, those who take part can work in a variety of roles in an interdisciplinary context - great experience and preparation for graduate employment.
More information is available at:

http://venturematrix.shu.ac.uk.

\section{Implementation (including barriers and enablers)}

One of the modules in the Mathematics programme at SHU provides an ideal opportunity for engagement with the Venture Matrix scheme. The module is called 'Mathematical Programming for Excel and the Web' and, as the title suggests, is intended to develop skills in creating mathematical applications delivered via a spreadsheet and over the internet. During the first half of semester 1 , students develop specific programming skills in Excel. In the second half they put these into practice through individual projects - chosen from a list offered by the tutor. The pattern is repeated in semester 2, with web programming in Javascript and PHP.

It is in the project parts of the module that participation in the Venture Matrix is possible, and it was decided to try running a pilot study to see how successful engagement between the Maths programme and the VM could be. Therefore, during the second semester of the past academic year (2009-10), students taking this module were offered the opportunity to take part in a particular venture as an alternative to one of the existing project choices. 
The venture in question was from a group of three Business Studies (BS) students who had created a venture called 'Employability Boosters'. They wanted to create an interactive quiz that could assess an individual's mathematical/numeracy skills - and needed partners who could create and implement the quiz. The BS students would be principally involved in creating the look and feel of the interface, and choosing the style and nature of delivery of the questions; the Maths students would devise the questions themselves and create and implement the quiz.

The project was necessarily different in nature from those normally offered in a number of ways:

- It would be a group project (involving up to three students) rather than an individual one

- This team would, in addition to the creating the product itself, have to engage in negotiation with the BS students to determine the specification and requirements for the product, and to liaise with them as the project progressed. Some degree of project planning and organisation would also be required.

- The assessment of this project would have to take account of the different nature of the project, and yet be equitable. Students are expected to write a report of the project, including a critical reflection of the outcome. In this case the students were asked to also write an account of their personal contribution to the overall project.

In the event, one group of three students wanted to try this project, and following a briefing by the tutor, were put in contact with the Employability Boosters team. They were advised to keep close records of all meetings that took place to discuss the progress of the project. Apart from maintaining an oversight, and offering technical support when necessary, no further tutor involvement was necessary.

\section{Evidence and recommendations In their evaluation of the project, the Maths students reported that:}

"The experience of working with the Employability Boosters has been a great chance to build our team and communication skills, whilst working within a professional environment. This project is definitely something that should be repeated, but only if the groups involved are willing to put a lot of time and effort into the scheme, with a shorter time frame. A lot of our work on this project took place whilst finishing the teaching section of the web programming. Thus we were still learning whilst we were creating the site.
Many people had not started this project until we were nearing the finishing stages so they need to be informed of the workload. However, the workload is balanced out by the crucial skills you are developing whilst working with the final years; communication being the main in my opinion."

\section{Comments from the Business Studies partners:}

- "Regular progress meetings [with the Maths students] were conducted in a professional manner with extremely good communication displayed between the groups.

- The [Maths students] showed good initiative and strong team skills.

- They were good at articulating the requirements of "non-technical" people and solving the problems through innovative design techniques.

- They showed great passion and determination to help with our real-life project.

To conclude, they couldn't have been more supportive in helping us and we are extremely grateful for this. We are delighted of the outcome and the group have met all of our key requirements efficiently and effectively."

The outcome was extremely successful - as evidenced by comments in the last section. It is clear that a major factor in this success is the fact that the group of students were very hard working, motivated and able. Some degree of selection is necessary when allocating projects of this kind, otherwise an acceptable finished product may not be achieved in the time available.

\section{References/more information:}

The finished project is available at http://maths.shu. ac.uk/students/webster_clare/EmployabilityBoosters/ Username: 'employability', password: 'boosters' 


\section{b: Peer Assisted Learning}

\section{Skills Addressed:}

Teamwork $\bullet$ Autonomy $\bullet$ Leadership $\bullet$ Communication $\bullet$ Presentation skills

\section{Jeff Waldock}

Engineering and Mathematics, Sheffield Hallam University

\section{Context}

There are many types of Peer Assisted Learning (PAL) schemes found across the HE sector, and most can be classified into two types - individual and group. The former involves more experienced students being paired individually with one or more less experienced students in an informal mentor/ mentee partnership. In the latter case PAL leaders provide support in a one-to-many group-based setting. This may be in the form of informal dropin help sessions, where any first year student who feels they need help can meet the PAL leader. A number of such schemes in Mathematics at UK HEls are in existence, some of which are identified in the reference list. A less common variant is where PAL leaders are assigned a small group of first year students, meeting at regular timetabled sessions to carry out specific activities. This is the model adopted at SHU.

\section{Implementation (including barriers and enablers)}

The scheme in the Mathematics programme at $\mathrm{SHU}$ involves a final year students acting as PAL leaders for groups of first year students throughout the first semester. In the current academic session (2009-10) there are 12 final year students each of whom facilitates a group of 7 or 8 first years who are working on small projects as part of one of their modules. Each group has to identify their own project topic, and organise themselves effectively. PAL leaders encourage the groups to undertake a Belbinstyle group role indicator test to help them identify appropriate roles. At the end of the semester, each group has to deliver a poster, an oral presentation and a written report - these form the basis for their assessment of this element of the host module.

The project is not intended to be especially challenging mathematically to the first year students - the idea is for them to make use of existing technical skills, and develop their teamwork, research, leadership and communication abilities.

The PAL Leader does not teach the first year students, but encourages them to recognise for themselves what they need to do - which of their group is best suited to which task, for example, and how they should make progress. It may involve asking searching questions of the group in meetings, guiding discussion or taking note of who is not contributing and finding ways of helping them get more involved. PAL leaders are provided with one day's training before the start of the semester to help raise awareness of these issues, and provide them with some practical suggestions.

The member of academic staff allocated to each group provides support to the PAL leader, and 
maintains overall responsibility for the smooth running of the sessions. Some choose to take an active part in the weekly sessions while others allow the PAL leaders to lead them.

Difficulties in setting up and running the scheme include the need for at least one person to champion the cause, devoting time and energy to motivate the participants and to stimulate enthusiasm for it. A lack of resource - principally staff time - will also inevitably be a major barrier to success.

It is very helpful to book rooms so that the PAL sessions appear on students' official timetables, however the constraints involved - finding times when both sets of students, staff and rooms are available - can be problematic.

Getting volunteers from the final year student group has not been a problem. These students are very focussed on their studies and are keen to gain a good degree grade, and since involvement in the PAL scheme does not - for them - provide any academic credit there was a concern that they may be reluctant to take part. Despite this, enough volunteers were keen to take part, suggesting they felt that the employability skills gained made it worthwhile.

One other important factor in final year student engagement with the scheme is that many of the students on the course plan to go into teaching as a career. They see the PAL scheme as a way of gaining very relevant skills, and of strengthening their $\mathrm{CV}$.

\section{Evidence and recommendations}

Evaluation sessions are held midway through the Semester, and at the end of the scheme in January. All participants were asked to comment on what they felt were the good and bad points of the scheme, and what they felt they gained from it personally. The PAL leaders felt they had developed their interpersonal and leadership skills, and that the experience would significantly enhance their $\mathrm{CV}$. Specific responses include:

"Being on the same wavelength as the PAL group aided rapport greatly. It is easier to be honest and speak up to a student PAL leader as opposed to a lecturer" - PAL Leader

"It's certainly made me more confident speaking up in front of a group of people I don't know. It gave me a good idea of how people work together in a group too, something that you don't notice as much if you're actually working within the group" - PAL Leader
"We got to ask questions and see how the uni life was. As the 'Pals' do Maths too they gave us advice on what to do and what is best. As we just started it helped us to form friends" - First year student

Benefits for PAL leaders include:

- developing personal skills such as leadership, teamwork, interpersonal communication, facilitation and coaching skills

- gaining confidence especially in situations when teamwork is required to attain a goal

- valuable experience to enhance their CV

- experience in managing groups

Benefits for the first year students include:

- smoothing the transition into HE by providing contact with more experienced students who can offer academic and pastoral support.

- helping with social integration

- learning team-working skills

Benefits for academic staff include:

- helping to foster a learning community

- practical help managing the tutor groups, and input into the assessment process 


\section{7: Progress Files}

\section{Skills Addressed:}

Reflection • Organisation • Action-planning • Communication

\section{Jeff Waldock}

Engineering and Mathematics, Sheffield Hallam University

\section{Context}

There is a considerable body of research literature supporting the claim that both student achievement and the development of graduate employability skills are enhanced by the inclusion within the curriculum of structured processes that develop the ability for self-reflection. Students should be able to identify their strengths and weaknesses, formulate strategies for addressing the weaknesses and plan for their own personal, educational and career development. This has a special impact in Mathematics, where students may have less well-developed skills of articulation.

\section{Implementation (including barriers and enablers)}

The Mathematics programme at Sheffield Hallam University has since 2001 incorporated a web-based Progress File system. The system requires each student to engage with the reflective progress on a continuous basis, providing regular reflective entries in their Progress File for each module, and receiving academic credit for doing so.

In year 1, students are expected to make entries for each module at least weekly. These entries are assessed, and provide $20 \%$ of the mark for one module. Each student receives simple weekly feedback in the form of a mark awarded against published assessment criteria. At the end of the year students provide a longer reflective summary of their development over this time, for which they receive fuller email feedback.

In year 2 the entries are marked every other week with the marks again contributing towards a core module. The logbook marks comprise part of a general employability element of assessment in this module, as students prepare to apply for an industrial work placement.

In the final year, the logbook assessment is built into the Project module, comprising 5\% of the 30 credits available. This keeps the Project work higher on students' list of priorities and helps tutors to track progress.

Although entries made by each student are hidden from other students, all are visible to staff, who can view all entries by a particular student, all entries for a particular module or simply the latest entries. Students quickly develop a culture of topping up their logbook entries at every opportunity, and so this last approach provides an extremely useful way for staff of getting feedback on lectures, for example, within hours of delivery. It also means that as a member of staff, you get a very clear idea of how your module material is being received across the whole group, and whenever a problem starts to occur it can be dealt with very quickly. The system provides an easy 
way to reply to a student entry by email, so this can be done very easily. It is much more effective than relying on staff-student meetings to gather feedback on the progress of the course - for one thing, it's much more immediate, so problems can be dealt with before they become serious. For another, it's much more representative - all students can provide comments, even those who might not otherwise have the confidence to contact staff.

The main barrier to effective student participation is their commonly held initial view that it is unrelated to their course, and a lack of clear understanding of its purpose. The first of these difficulties can be addressed by engaging students in a shared discussion around what it might take to make them a more effective student, and raising their level of achievement.

The second difficulty can be tackled both by a clear explanation, repeated as necessary, of the purposes and benefits of the process of self-reflection, and by seeing (through trying it out) that it does in fact work. Once a student finds that they gain a real benefit from the system, their engagement should improve.

For staff the principal barrier is the time required to read and respond to comments (and to assess the entries). Although staff perception is that regularly reading and responding to the latest comments is quite time consuming, this can actually be done very easily because of the way the system is set up. Furthermore, this is offset by the benefits that follow from the rapid resolution of problems - improved retention, student satisfaction and engagement and the development of a shared community of learning.

\section{Evidence and recommendations}

At the end of each year, first year students are asked to provide a summative review and feedback of the system: ".. the progress file has helped me to develop my communication skills and to become more confident in talking about my own work .. it allows you to see how you have progressed, or dealt with any personal problems."

A further measure of success comes from the National Student Survey. The last three of the 21 specific questions address students' personal development:

Q19: This course has helped me present myself with confidence,

Q20: My communication skills have improved,

Q21: As a result of the course, I feel confident in tackling unfamiliar problems
In 2008, the scores for Mathematical Sciences at $\mathrm{SHU}$ was $91 \%, 91 \%$ and $94 \%$ for these three questions, respectively. In 2009, the scores increased to $95 \%, 95 \%$ and $97 \%$ respectively. Nationally, Mathematical Sciences at SHU has been ranked 1st for this area in each of the last three years 2007-9.

From the experiences at $\mathrm{SHU}$, there are a number of important features that an e-PDP system should have in order for it to work effectively:

- A key staff champion is needed to take responsibility for developing the system, and for selling it to all participants.

- It needs to be very easy to use (both for staff and students).

- It also needs the active engagement of staff. Students clearly perceive the logbook as having more value if they receive prompt replies or feedback to their entries.

- Although students understand the importance of developing employability skills, they prioritise their work according to credit received, so it is important that the logbook entries are assessed.

- The system needs to be embedded into the curriculum, becoming an important element of normal academic activity on the course.

- The process is more important than the tool used. Student engagement is the key and PDP should not become a tick box activity.

Students are active partners in learning, and the purpose of each activity should be explained and justified to them. Progress Files are no exception!

\section{References/more information}

http://employability.shu.ac.uk/casestudies/ JeffWaldock.pdf 


\title{
B: Learning, Teaching and Assessment Approaches to Developing Graduate Skills for Employability
}

\author{
Skills Addressed: \\ Self-awareness • Self-organisation • Autonomy
}

\section{Jeff Waldock}

Engineering and Mathematics, Sheffield Hallam University

\section{Context}

One of the principal barriers to the introduction into the curriculum of processes that develop graduate skills is the perception that this will reduce the space for mathematical content. There are several responses to this. One is the possibly radical suggestion that we include more content that is necessary, given the type of employment that the majority of mathematics graduates progress to. Certainly, the number of graduates that follow a research career, for whom the content is necessary, is small; for the rest, there is considerable value in the inclusion of processes that explicitly develop their ability to work in teams and to communicate clearly, as well as the more mathematical skills such as logical thinking and problem solving. The first argument, therefore, is a philosophical one - concerned with the fundamental question of what a particular programme's aims are, and what it is we expect a graduate from it to be able to do.

A second argument - equally important - is that the curricular content is not necessarily curtailed by the inclusion of processes designed to develop graduate skills. There are ways of organising the delivery and assessment of the material which can develop these skills at the same time as delivering the existing core content.
Thirdly, a related argument concerns the student perspective of their degree course as a whole. Do we do as much as we can to help them see how each course based activity, each lecture, tutorial, seminar and element of assessment, is designed as part of an organic whole; how each complementary piece fits together, leading to the rounded graduate we hope to see at the end of the course? If each student is able to see how, like a jigsaw puzzle, each activity fits into the big picture, their levels of engagement (and hopefully achievement) will increase, as well as their satisfaction with the course.

\section{Implementation (including barriers and enablers)}

On the BSc Mathematics programme at Sheffield Hallam University, students are made explicitly aware of the course aims, and of the need for generic skill development before they apply, as it is discussed at open day presentations. It is important that students understand that since there is no HE equivalent to the National Curriculum, there are a variety of mathematics degrees around, and they need the information necessary to make the right choice.

The programme is designed so that skills development is thoroughly embedded in all aspects of Learning Teaching and Assessment, at each level. Some examples are: 
Throughout the course, students use an electronic logbook to reflect on progress, to identify problems and to develop action plans to resolve them. This is discussed in more detail in the Case Study on p24.

Students in year 1 work in small teams on a project for one particular module, and are expected to deliver an oral, written and poster presentation on the results.

As part of a different module, they are expected to write an essay, reflecting on their own skill development, identifying where in the course each of the key skills is being addressed and relating this to the Mathematics benchmark statement. They are supplied with links to a range of relevant and recent electronic publications, so that they gain a better awareness of current and pedagogical issues.

As far as possible all assignment briefs highlight what skills that work is helping develop.

To address the problem of developing skills at the same time as retaining sufficient course content, a wide variety of approaches to learning, teaching and assessment are employed.

Group work is used at all levels to encourage the development of team-working skills; part of the assessment involves self and peer assessment, to reward this aspect of skill development.

Communication skills are developed in a variety of ways: written communication through essays, reports, poster presentations, electronic presentations and a final year dissertation. All students create and maintain a personal website - their electronic portfolio of work - leading to the development of skills in electronic communication. The use of web 2.0 social networking tools is not currently embedded in the course; it is currently felt that these are best kept extra-curricular.

Oral communication is developed through presentations - in a 'low stakes' group setting in year 1, through to individual presentations delivered to a larger audience as part of the final year project.

In terms of barriers to success, it is important that a consistent approach is adopted by all staff teaching on a particular programme. There needs to be a shared understanding of the underlying philosophy in terms of course delivery and assessment, which is sometimes difficult to achieve in practice. There may also be institutional constraints that limit the ability of the course team to operate freely.

\section{Evidence and recommendations}

The best evidence for success comes from student feedback:

"I feel the Hallam Maths course has had a massive impact on me and my career. I found that the way the course was delivered helped me engage with maths a lot more and built confidence in my ability."

"The Hallam maths course was a great foundation for my career because it not only provided the theory, but allowed us to apply that theory to real problems in a way that workplaces use."

"As an individual, I now feel more confident because I have gained many new skills."

"I feel that the way in which the course encouraged me to investigate problems has been of great benefit during my PhD. I seem to be more confident in my ability to work without supervision than some of my peers who did a more "traditional" math degree. The progress files in particular gave me the idea of keeping a daily log of what I have done and this has been invaluable when it comes to writing up my research." 


\title{
7: Placement Preparation
}

\author{
Skills Addressed: \\ Career management $\bullet$ Interview preparation $\bullet \mathrm{CV}$ development
}

\section{Jeff Waldock}

Engineering and Mathematics, Sheffield Hallam University

\section{Context}

The BSc Mathematics programme at Sheffield Hallam University includes an optional industrial placement year, between the second and final years of academic study. Students are encouraged to complete a placement, firstly because of the marked improvement in employability that it brings, but also because the improved skills in self-management, organisation and work ethic that students get from a placement also help them gain better final year grades. Students who do not wish to do a placement - even after these facts are presented to them - go directly to the final year, and complete a full-time degree.

Students wanting to do a placement register with the Faculty's placement unit, and are interviewed on their preferences (job type, location etc). They are then notified as relevant opportunities arise, and must then prepare an application; if shortlisted they will also need to prepare themselves for the interview. During the first half of the first semester, the course curriculum includes a series of placement preparation classes which aim to provide students with skills to help in this process.

\section{Implementation (including barriers and enablers)}

The placement preparation sessions form part of one of the second year modules - equivalent to $6 \%$ of the academic credit for the year. There are six sessions provided, as follows:

- Week 0 (during induction week): Career intentions, opting in or out of placements, preferred jobs and locations.

- Week 1: Presentation from Careers service; careers options questionnaire; guidance on CV development; assess/ discuss own CVs

- Week 2: Making a job application - Researching the company, writing covering letters. Personality tests - try one and read/analyse the feedback. Understanding what employers are looking for.

- Week 3: Handling difficult questions - see some, try some, discuss some. Be prepared!

- Week 4: Attend poster presentations given by students returning from placement. Interview students and mark at least 3 of them.

- Week 5: Choose one of a selection of sample job advertisements, and make an application for it.

- Week 6: In a whole-class setting, carry out an interview of 2 or 3 students (volunteers!) for the job 
applied for in week 5. Discuss afterwards with the whole group.

Each week, students hand in a summary of their work for assessment.

\section{Evidence and recommendations}

One of the main problems when running sessions developing general skills such as these is the need to demonstrate their relevance, so that students engage productively with the exercises. Although there were a number of students who did not want to take an industrial placement year who did not find the session very useful, the majority do have a keen interest in what lies ahead of them after finishing their degree, and can see that a placement year will provide them with invaluable experience to enhance their $\mathrm{CV}$.

Some of the comments received demonstrate that they saw value in these activities:

"We looked at job vacancies and then had to write a covering letter to go with that particular vacancy. I found this very useful as, had i had to do it alone, $i$ would have struggled knowing what to write. I have now got the basic draft of a covering letter and know how to set it out and make it look professional."

"So far i have found the employability lecture to be very helpful, i have never felt confident about writing a cover letter or how to answer difficult questions posed on Application forms or in interviews"

"I found that filling out the application form questions was difficult but was also very helpful, it got me thinking about myself, and what l've achieved and where my skills lie. I felt that it helped to talk to someone that knew me really well to see how they thought I could answer the questions too and it's strange what you forget or don't realise is actually a big achievement."

"Working in pairs we had to assess people's covering letter, C.V and application form, as well as state whether it was tailored to the job specification. I found this quite hard to do as we were criticising people's work, however I think it was a really good exercise and has given us a more in-depth insight into what needs to be included when applying for a job."

"Employability has been so helpful in making me realise what is needed to become a successful applicant in any job. I would have never fully understood the process of getting a full time job which would hopefully lead to a career if it wasn't for employability."
"This lecture nicely wrapped up this component of the module as we got to see an example of a live interview and the sort of questions that would be asked. You could feel the atmosphere which was great and you got the chance to comment on the positives and negatives of the interviewee."

"Today was our final formal tutorial for employability and I really enjoyed it as [student 1] and [student 2] had to go through an interview. This gave me a really good idea of what not to do in an interview."

"I found this session the most useful, as I have never had a formal interview, and so it has helped me in what I need to do on entering the room, as first impressions count for a great deal. From this session I have taken techniques that I am able to use in interviews of my own to improve my chances of being employed." 


\section{0: Using Art Gallery Problems to develop mathematical and} employability skills in a higher education group project

\section{Skills Addressed:}

Identifying assumptions in mathematical arguments • Referencing •

Communicating using reports and presentations • Team working

\section{Peter Rowlett}

Science \& Technology, Nottingham Trent University

(now working for MSOR Network, University of Birmingham)

\section{Context}

Transferable skills are an important part of undergraduate mathematics education [1] [2] [3], contribute to graduate employability [1] [2] and help satisfy employer need [4] [5]. However, it is not always apparent to students that skills development should form part of their curriculum [6] [1]. Group work can be used for the development of skills [6] [7], but may be less well suited to the introduction of difficult new mathematics [3] [6] [8]. Skills training and guidance can be helpful, rather than just asking students to perform tasks and hoping skills development follows [1] [6]. There are issues in group work of determining equality of contribution [6]. Peer assessment is recommended [8], perhaps in the form of formal minutes indicating actions and progress [5].

'Problem Solving' is a 20 credit, year long, second year module for BSc (Hons) Mathematics students. It has no pre-, post- or co-requisites. The module aims and outcomes refer to the development of transferable skills rather than to a specific mathematical syllabus so the use of group work and projects is in accordance with the findings in the literature.

\section{Implementation (including barriers and enablers)}

Students were required to research a mathematical topic in groups to answer set problems, then to explore the topic in a direction of their choosing. The topic of Art Gallery Problems - determining the number of guards needed to keep every point in a room under surveillance - was chosen as requiring no prior knowledge and being mathematically simple from first principles. Original research in this area was motivated as "an interesting geometric problem" ([9], p. 1) and not as an applicable technique. Many simplifying assumptions make these techniques practically unworkable.

Students completed an 8 week group project, presented as if for a 'client', which asked them to provide justified answers for 12 specified museum layouts. Encouraging students to research and apply pure mathematics techniques as though they were applicable to the real world means there is plenty of room for critical thinking. In applying mathematics, it is important to consider the assumptions made and the limitations of the model used. In many areas these can be quite subtle; for Art Gallery Problems they are quite apparent and this provides an excellent teaching tool.

Groups gave their answers in a report to the non-mathematical 'client' and documented their techniques as an in-house technical report, in which they provided a critical analysis of the appropriateness and limitations of the model used and outlined some possible extensions of the theory to address these. Group presentations outlined the research into possible extensions. 
No formal training was given on the topic besides an indicative initial reading list. Skills development activities were given on 'Teamwork' and 'Questioning the assumptions in a mathematical argument' and more structured classes on 'Finding and using references', 'Report writing' and 'Giving presentations'.

Marks were assigned for both reports, the presentation and for group management. This latter was for a 400word plan of work, one week after the problem was set, and minutes from weekly group meetings showing actions and progress for each member and progress against the plan of work.

\section{Evidence and recommendations}

A feedback questionnaire in the first class after completion of the project was completed by 28 students out of 36 .

- Suitability of content: All agreed the project did not require prerequisite mathematical knowledge. The majority rated the difficulty, compared with other modules, as "easier" (13/28 students) or "about the same" (13/28).

- Skills training: Students were asked to rate the "usefulness in completing the project" of the structured skills development sessions. Most found the sessions helpful: 'Finding and using references' (20/28), 'Report writing' (20/27) and 'Giving presentations' (16/25).

- Enjoyment: A majority enjoyed "Undertaking selfdirected learning" (18/27) and "Working as part of a team" (17/28). There was almost an equal number enjoying and not enjoying "Giving presentations", "Writing for a business audience" and "Writing for a technical audience". A substantial minority (9/28) did not enjoy "Art Gallery Problems as a topic".

- Team working: 24 agreed and two were unsure about the statement "This project fostered team cooperation and oral communication" (taken from [7], p. 47).

\section{- Group management and equal contribution:}

20 felt the plan of work was helpful in organising the project and 6 were neutral. 16 felt the minutes were helpful, 8 were neutral and two felt these were unhelpful. Particularly, 6/8 group Chairs and 5/6 Minute takers felt the minutes were helpful. However, only 12 agreed: "All team members contributed to the project equally"; 7 disagreed and 7 were unsure.

\section{- Importance of skills development and its place} in the curriculum: All 28 agreed: "A mathematics graduate should have transferable skills". 18 students agreed, eight were neutral and two disagreed with: "A mathematics student should be taught transferable skills as part of their degree (for credit)".

\section{Conclusions}

Skills development was regarded as important but students were less certain that this should form part of formal curricula. Art Gallery Problems provide a useful topic for skills development, not requiring prerequisite knowledge or being too difficult, but were not liked by all students. Plan of work and minutes of meetings were regarded as an effective method for team management but not as completely effective in ensuring everyone makes an equal contribution. The provision of skills training sessions was regarded as useful. Some student comments: "I feel that my transferable and group work skills have improved"; "Excellent eye-opener ... into the world of business; deadlines and expectations"; "This module has really helped me realise my potential, given the boost I needed for my future after university." But, as a warning: "Don't subject future 2nd years to this assignment."

\section{References/more information}

1. Challis, N., Gretton, H., Houston, K., and Neill, N. Developing transferable skills: preparation for employment. In: P. Kahn, ed. and J. Kyle, ed., Effective Teaching and Learning in Mathematics \& its Applications. London: Kogan Page, 2002, pp. 79-91.

2. QAA. Subject benchmark statements: Academic standards - Mathematics, statistics and operational research. Gloucester: The Quality Assurance Agency for Higher Education, 2002.

3. Kahn, P. Designing courses with a sense of purpose. In: P. Kahn, ed. and J. Kyle, ed., Effective Teaching and Learning in Mathematics \& its Applications. London: Kogan Page, 2002, pp. 92-105.

4. Hibberd, S. Use of Projects in Mathematics. MSOR Connections, 2005, 5(4), pp. 5-12.

5. Lowndes, V. and Berry, S. Benefits of using Industrially based Group Projects within Mathematics Programmes. MSOR Connections, 2003, 3(1), pp. 20-22.

6. MacBean, J., Graham, T. and Sangwin, C. Guidelines for Introducing Groupwork in Undergraduate Mathematics. Birmingham: HEA Maths, Stats and OR Network, 2001.

7. Ahmed, A., Holton, D. and Williams, H. Developing active learners. In: P. Kahn, ed. and J. Kyle, ed., Effective Teaching and Learning in Mathematics \& its Applications. London: Kogan Page, 2002, pp. 34-48.

8. Hibberd, S. Mathematical modelling skills. In: P. Kahn, ed. and J. Kyle, ed., Effective Teaching and Learning in Mathematics \& its Applications. London: Kogan Page, 2002, pp. 158-174.

9. O'Rourke, J. Art gallery theorems and algorithms. New York, NY, USA: Oxford University Press, 1987. 


\title{
ll: Graduate "skills" Development Programme (GDP)
}

\author{
Skills Addressed: \\ Reflection $\bullet$ Teamwork $\bullet$ Communication $\bullet$ Presentation skills $\bullet$ Employment awareness
}

\section{Kevin Golden and Guy Roberts}

Engineering Design and Mathematics, University of the West of England (UWE)

\section{Context}

In 2006, UWE launched a university-wide Graduate Development Programme to deliver a consistent approach to the development of "graduate skills and attributes" for undergraduate students. The development of the programme followed a University employability project which identified a number of skills and attributes sought after by employers of graduates, regardless of discipline. The same research revealed a high level of expectation from an overwhelming majority of undergraduates that the University had a responsibility to "make them more employable". The top ten skills and attributes identified by the employability project were team working, motivation, initiative, problem solving, independent working, confidence, resilience, interpersonal skills, emotional intelligence and being open minded. While the academic programmes of study themselves cover a number of these skills, it was felt that others required additional resources and a specific focus to ensure that students were supported throughout their studies and prepared for the world beyond university.

\section{Implementation (including barriers and enablers)}

The planning of the content of each GDP programme was devolved to the programme level with the caveat that certain themes are covered at particular stages of a programme of study and that the delivery style is student centred. The overall aim of the programme is to encourage students to be reflective and self critical and to update their skills and personal profiles as they develop through their degree. Activities are defined at different levels as shown in figure 1 overleaf.

The level 1 programme is delivered to mathematics students in group sizes of sixteen over twelve sessions. For the other levels the group sizes can vary depending on the activity and the number of sessions reduced to eight sessions for level 2 and four sessions for level 3. The style of each session is that it should be student led with the academic acting as a facilitator. On completion of each level, students receive a GDP certificate provided they submit a short essay reflecting on the progress they have made during the year.

The main barriers for the success of this type of scheme are generally concerned with staff and student engagement. Resources are allocated to GDP tutors to prepare and deliver sessions, but in addition to this a series of training events were held prior to the start of the programme to introduce what to many academic staff was an unfamiliar style of "teaching". GDP coordinators were identified for each programme and encouraged to share materials and approaches. A University-wide review of the GDP scheme is an ongoing part of the University calendar. The scheme is promoted to students as an integral 


\begin{tabular}{|c|c|c|}
\hline Level 1 & Level 2 & Level 3 \\
\hline - Transition to university & - Transition to level 2 study & - Transition to the final year \\
\hline $\begin{array}{l}\text { - Making use of feedback } \\
\text { (tutorials, coursework, reflection, } \\
\text { exam preparation) }\end{array}$ & $\begin{array}{l}\text { - Employability (updating CVs, } \\
\text { applying for placements, } \\
\text { employer engagement talks) }\end{array}$ & $\begin{array}{l}\text { - Finding employment } \\
\text { (updating CVs, employer } \\
\text { engagement talks) }\end{array}$ \\
\hline $\begin{array}{l}\text { - Projects (research skills, } \\
\text { leadership, managing groups, }\end{array}$ & $\begin{array}{l}\text { - Final year projects (What is } \\
\text { involved, developing a project, }\end{array}$ & $\begin{array}{l}\text { Continuing professional } \\
\text { development }\end{array}$ \\
\hline teamwork, presentations) & finding a supervisor, preparation) & - Managing final year projects \\
\hline $\begin{array}{l}\text { - Employment awareness } \\
\text { (CV preparation, placement } \\
\text { opportunities) }\end{array}$ & & \\
\hline
\end{tabular}

Figure 1: Outline of GDP programme

part of their studies. During open days and induction, the GDP programme is given high visibility with various promotional materials.

To date, for mathematics students, the GDP programme has been delivered as a stand-alone programme, providing an additional resource to promote awareness of important issues that can appear to fall outside the remit of the mathematics modules. This is particularly true of issues concerning the employability of mathematics graduates and is valuable given that many new mathematics students are unaware of the employment opportunities open to them. However, in the next academic year a number of the GDP sessions will be integrated into the academic programme delivery. This is partly to ensure that more students engage in this ongoing skills development but also that a number of modules are changing the way material is delivered to provide enhanced opportunities for feedback through regular group discussions and presentation of work.

\section{Evidence and recommendations}

It is probably far too early to comment on the success of the GDP programme since only two cohorts have completed their degrees while the programme has been in place. During the past four years we have increased our student numbers and increased the tariff on entry to the mathematics degree while maintaining good progression statistics. So we cannot claim that this performance is to do with the implementation of a skills programme as opposed to recruiting stronger students.

In each of the years of running the GDP programme between one third and one half of the first year students have submitted a reflective essay at the end of the year. While this participation is low, it should be noted that submission is voluntary. Among those who submit this essay, there are some very interesting comments which show that they have clearly developed their perception of what their degree is about and focus over the year. The essays provide valuable feedback about their view of particular modules. The views expressed are generally constructive and honest about their own strengths and weaknesses and about the experience of studying our programme. In the vast majority of cases the students are very positive about their experience at the University. In one sense they provide more valuable information than that obtained from end of module questionnaires. Completion of the programme at levels two and three is much lower although attendance at sessions involving final year options, projects and placements is generally high.

The changes we are making to the programme this year are partly motivated by a desire to increase participation at level one. This is where we need students to settle and make the transition from school to higher education. While evidence for success is mixed, it seems that there is a clear benefit at level one to those who engage, although it is also probably true that our most engaged students are those who participate in the GDP programme. That said there is real value in the feedback these students have provided to us.

The University always envisaged that the GDP programme was more than a skills development programme, but that it would influence the way we taught our modules. Four years into the programme we can see this process starting in the mathematics degree.

\section{References/more information}

Description of UWE GDP programme http://www.uwe.ac.uk/gdp/index.shtml 


\title{
1ㄹ: Writing Mathematics
}

\author{
Skills Addressed: \\ Writing • Thinking
}

\section{Kevin Houston}

School of Mathematics, University of Leeds

\section{Context}

The University of Leeds is a redbrick Russell Group university in the north of England. The School of Mathematics has a yearly intake of about 144 UK/EU students and about 25 international students. The standard A-Level offer is AAB with A in Mathematics.

The writing of mathematics is generally not considered a high priority in the education of mathematics students. A student can often achieve full marks in a homework assignment or exam provided that they supply the correct numerical answer or give enough correct words and phrases to convince the marker that they know what they are talking about.

There are a number of reasons for this state of affairs. From the marker's perspective it is easier to mark a piece of work if all one looks at is the final numerical answer. Also, by providing less information or just a jumble of mathematical symbols rather than a wellargued mathematical proof, students stand a better chance of not betraying their ignorance and hence the risk of losing marks.

Furthermore, students are happy because it involves less work and not just concerning mundane writing skills such as spelling and grammar. In fact, often they are doing less thinking about their mathematics.
Effectively, they don't need to concentrate on organizing their thoughts coherently.

Over a number of years I have aimed to encourage mathematical thinking by concentrating on ensuring that students present their mathematics correctly.

For many years first year mathematics students were assigned to groups of six. Each group was assigned a Pure, Applied and Statistics tutor. These tutors were mostly lecturers though it was not unusual to have postgraduate students fulfil the role. Of the three tutors, generally one would be a personal tutor who would provide pastoral care to members of the group during their time at university. (Only a lecturer could be a personal tutor.)

All students would attend lectures and the homework would be discussed in weekly tutorials. The tutor would mark and return the work to their tutees.

\section{Implementation (including barriers and enablers)}

For my tutees I marked their weekly work with attention paid to writing coherent mathematics. For example, one very important condition for coherent mathematics is that students should write in sentences. Hence any student who provided a jumble of unconnected symbols would receive lower marks. 
A booklet, How to Write Mathematics (available on my website) is supplied to all our first year mathematics students. I expected students to follow all the advice in the booklet. However, I concentrated on particular pieces, such as writing sentences (as this is a basic building block of communication) and writing equals only when objects are equal. The abuse of the implication symbol is a common problem with students and so this was ruthlessly picked up on.

Barriers to implementation include resistance from students. Common complaints are that I knew what they meant, or they didn't come to university to write essays. One reason for resistance is that it forces them to think and partly that is the point. If they can't write the mathematics properly then it is likely that they don't really understand it.

The teaching atmosphere plays a part. If other lecturers are not penalizing poor exposition, then students may feel that they are being unfairly treated by the one that does and this may be reflected in negative questionnaire evaluations which may be a concern. One problem is that students often do not appreciate until afterwards that they have been learning a useful skill.

As I have recently discovered one important enabler is small group size. It is much easier to provide extensive feedback to students when one has a small group. The structure of first year tutorials has now changed at Leeds (to provide a better experience at higher levels). Now, I mark 30 scripts per week rather than 6 . Furthermore, the student group alternates every other week. This means it is harder to provide as much feedback and guidance as it is harder to keep track of an individual's problems.

\section{Evidence and recommendations}

Students are strongly motivated to maximize their marks and so if poor exposition is not penalised with withdrawal of marks or encouraged by giving marks, it is unlikely that students will alter their behaviour. In particular, though How to Write Mathematics is supplied to all our first year mathematics students, they do not read it unless they are losing marks due to not following the advice.

Using the booklet makes returning feedback a lot easier since I can just quote section and page number rather than writing a long explanation of why they are wrong.
I would recommend constantly reminding the students that good writing skills are valued by employers and they will also improve their thinking so later work will be easier. Also, if the marking is too ruthless then students can be dispirited, which is one reason I concentrated on particular aspects such as writing in sentence.

Often a student can be seen to "get it" when they start writing long and detailed answers. This is not a problem as the students can be quickly guided into making more concise answers and so I view the "overwritten" answer as a good sign.

Evidence that the method works is (unsurprisingly) rather anecdotal. For example, during tutorials, when discussing writing up answers, students would quote back section titles of the booklet to me such as "Equals means equals". Also, once whilst anonymously marking a second year exam I was able to detect one of my students because their explanations were very good (even when wrong!). The main evidence is that students thank me later. Generally they are grateful at the end of the year that they realise they have learned a useful skill.

\section{References/more information}

Teaching how to think like a mathematician: writing mathematics, Maths at University: Reflections on experience, practice and provision, ed., M Robinson, $\mathrm{N}$ Challis and M Thomlinson, 174-177.

How to Think Like a Mathematician, Kevin Houston, CUP 2009. In particular chapters 3 and 4 which are available via my web page http://www.kevinhouston.net and in video form at http://www.youtube.com/user/DrKevinHouston 


\section{3: Student teams developing mathematical models} applied to business and industrial mathematics

\section{Skills Addressed:}

Developing mathematical models $\bullet$ Problem solving $\bullet$ Group work $\bullet$

Presentation skills $\bullet$ Organisation • Action-planning $\bullet$ Communication $\bullet$ Reflection

\section{Edmund Chadwick}

Physics and Mathematics, University of Salford

\section{Context}

The University of Salford and recently started a new undergraduate degree programme in mathematics, with a strong focus on application and input from business and industry. There is a desire for graduates to be business-aware and business ready. This case study attempts to address this and in doing so prepare for the world of work.

\section{Implementation (including barriers and enablers)}

Seminars from guest speakers on a spectrum of mathematical applications used in industry are to be presented to the undergraduate mathematics cohort. Two problems, one from industry and one from business (finance) will be presented, each requiring the development of a mathematical model. Students will each have a specific role within a group that will arrange meetings between themselves and also an academic adviser. A variety of assessments and methods will be used to assess business-like teamfocussed attributes.

The project described in this case study is trying to give students experience of business and industrial working practices and how to solve practical mathematical problems not through a traditional academic route by examination or essay, but instead by a pro-active approach through a team-based problem-solving format familiar to the world of business and industry. Exposure, understanding and experience on the development of mathematical models from concept to testing is key.

The project is also trying to expose the students to various roles played within a team, and to assess their preferences, performance and capacity for changing role particularly in the context of developing mathematical models. There is an academic adviser to the groups who plays only a supportive role, the idea being that it is the group themselves that comes up with their own solutions. The academic adviser will also be observing and noting the interaction between the members of the groups, and also how they adapt to being given roles that may not be comfortable for them; the adviser will change the roles of the group members between semesters. Both the adviser and students will subsequently provide reflective comments on this experience to share with the group at the end of the module as part of the personal development process.

The four roles in each group are chair, secretary, task coordinator and technical coordinator. They will have worked on developing a mathematical model from concept, design, solution, to testing, and produced a minutes book, project plan, specification 
and final report within which is detailed their mathematical model.

They will have had real experience of the type of roles played within teams, and be able to reflect upon how this dynamic directed the outcome of the final solution presented in their mathematical model.

In particular, a key theoretical/educational outcome for this case study proposal is to investigate what role the dynamics of the group played in the outcome of their particular solution to the problem.

\section{Evidence and recommendations}

This project has support and funding from the Mathematical Sciences HE Curriculum Innovation Project, part of the National HE STEM Programme.

Student and outside speaker feedback is very positive. Students in particular feel engaged, some for the first time by being in a pro-active rather than passive environment, where they feel they are creating something themselves rather than reiterating existing material. The collation and evaluation through feedback forms is on-going.

\section{References/more information}

Assessing student teams developing mathematical models applied to business and industry National HE STEM Programme project, MSOR Network, 2010. 


\section{4: A series of l2 study skills booklets}

\section{Skills Addressed:}

As indicated by booklet titles below:

- Creating examples

- Taking mathematics apart

- Proof - what is the game?

- Unpacking symbols

- Writing mathematics well

- Assessment

- Learning to do algebra

- Using diagrams

- Handling your emotions

- Approaching numeracy as an adult

- Mathematical problem solving

- Getting to grips with statistics

\section{Peter Samuels $s^{l}$ and Gareth Williams (plus one leaflet was drafted by David Bowers ${ }^{3}$ from University (ampus Suffolk)}

${ }^{1}$ sigma Centre for Excellence in Mathematics and Statistics Support (sigma CETL) (now working for the Academic Skills Centre), ${ }^{2}$ Department of Pure Mathematics, Coventry University (now working for Birmingham City University), ${ }^{3}$ The Open University

\section{Context}

The vast majority of available UK HE mathematics resources (e.g. those available from www.mathcentre. ac.uk, accessed 22/12/10 and https://cuportal. coventry.ac.uk/C13/MSC/Document\%20Library/ worksheets.aspx, accessed 22/12/10) are topic based rather than skill based. The intention of this Project was therefore to complement these existing resources but also to complement The Open University's existing maths study skills website (http:// maths-study-skills.open.ac.uk/, accessed 22/12/10) which is targeted at Level 2 (Year 2) and Level 3 (Year 3) mathematics students by emphasising the mathematics appropriate for Level 0 (foundation year) and Level 1 (Year 1) undergraduate students. However, some of them may also be appropriate to students on Level 2 and Level 3 courses studying numerate modules. The idea of producing maths study skills leaflets was also inspired by a similar style of leaflets on academic writing in Coventry University's Centre for Academic Writing (see Deane, Samuels \& Williams, 2009). 
sigma CETL sponsored Gareth Williams on a secondment to this Project.

\section{Implementation (including barriers and enablers)}

Samuels and Williams first carried out an evaluation of existing web-based resources on maths study skills in UK HE (for details of their findings, see Samuels and Williams, 2010). They then decided to produce single page leaflets ( $\mathrm{A} 4$ folded into an $\mathrm{A} 5$ booklet) on individual topics. They first decided on the topics with guidance from Kahn (2001). They then divided them between the two of us according to our expertise. They worked together when writing the leaflets and proofread each other's drafts.

They used a consistent style for the leaflets and visual icons acting as mental cues (such as examples, advice and exercises).

In terms of the involvement of others, Mary Deane from Coventry University's Centre for Academic Writing was very supportive of the Project and helped with the academic dissemination. Peter Kahn from the University of Liverpool, the author of a textbook on maths study skills, kindly attended a meeting and gave some helpful advice. Martin Greenhow from Brunel University, the author of a website guide on general study skills and a mathematics lecturer, kindly reviewed their article for MSOR connections and made some helpful suggestions.

Samuels and Williams tried to create a wider development community for this project by informing and inviting the authors and main contacts of the other existing UK HE web-based maths study skills materials. They also set up a JISCMail list (maths-study-skills@jiscmail.ac.uk). However, neither of these initiatives has led to much significant activity. students but the majority did not feel strongly about them. Accordingly, their inclusion appears harmless.

- Students resisted engaging with the activities, but when pressed to do so, found they made valid points which the students had not previously considered. This serves to reinforce the importance of engaging activities, and also highlights the challenge of persuading students to engage.

Further evaluation and improvement of these leaflets is anticipated in the future.

Samuels now works for Birmingham City University and has made extensive use of the leaflets on approaching numeracy as an adult, handling your emotions and getting to grips with statistics. He has observed that an additional leaflet on taking employer numeracy tests is also needed. Other leaflets on using technology and reading mathematics are also planned.

\section{References/more information}

These leaflets are all freely available as pdf files from http://www.sigma-cetl.ac.uk/index.php?section=102 (accessed 22/12/10).

Deane, M., Samuels, P. C. \& Williams, G. R. (2009) Developing Students' Academic Literacy and Mathematical Self-Efficacy through Multi-media Learning Resources, LDHEN '09, Bournemouth, http://www.aldinhe.ac.uk/bmth09/papers/Samuels_ paper.pdf, accessed 22/12/10

Kahn, P. (2001) Studying Mathematics and its Applications, Basingstoke: Palgrave

Samuels, P. C. \& Williams, G. R. (2010) Developing students' self-efficacy through mathematical study skills resources, MSOR Connections, 10(2), 26-30

\section{Evidence and recommendations}

The leaflets have been made available at Coventry University, The Open University and Birmingham City University and have also been downloaded by other institutions.

A sample of students at Coventry University was exposed to a selection of the resources in 2008. Feedback was generally positive, in particular:

- Students are unaware of the importance of contextualised study skills and hence may struggle to overcome associated barriers.

- The visual icons were well received by some 


\section{5: Every Student Counts: Promoting Numeracy and Enhancing Employability (a project funded by the NTFS Project Strand - 200?)}

\section{Skills Addressed:}

Numeracy skills, particularly in the context of graduate employability

\section{Vicki Tariq}

Learning Development Unit, University of Central Lancashire

\section{Context}

The government, employers and other stakeholders increasingly expect universities to ensure their degree programmes foster students' employability skills with a view to producing 'work ready' graduates; the non-exhaustive list of such skills includes 'numeracy'. Smith reported that employers across a range of sectors demanded a mathematically skilled workforce and regarded "an adequate supply of young people with mastery of appropriate mathematical skills at all levels ..... vital to the future prosperity of the UK" (Smith, 2004: 12, original emphasis); a demand reinforced by the fact that numeracy skills invariably appear in the top five or ten skills reported to be required by employers.

\section{Implementation (including barriers and enablers)}

Part of this three-year project (2007-2010) involved ascertaining: the generic numeracy skills in which employers expect their graduate recruits to be competent and the extent to which employers use numeracy tests as part of graduate recruitment processes; the numeracy skills being developed within a diversity of academic disciplines; the prevalence of factors that influence undergraduates' development of their numeracy skills (e.g. their conceptions of mathematics, attitudes towards numeracy skills, and mathematics anxiety); how undergraduates and their tutors believe the development of numeracy skills might be better supported within undergraduate curricula and what extra-curricular support might help enhance such skills (Tariq, et al., 2010). The study involved samples of 566 undergraduates and 122 tutors from a diversity of academic disciplines across all four faculties at a post-1992 university, and 165 employers of graduates. A mixed-methods approach was adopted using surveys, complemented with student focus groups and tutor interviews.

Data obtained confirm the importance that employers attach to graduates' numeracy skills, the widespread use of numeracy tests in selection procedures and thus the potential for graduates' poor numeracy skills to limit their procurement of employment commensurate with their career aspirations (Tariq, et al., 2010). They also revealed the extent and diversity of existing opportunities for intra- and extra-curricular numeracy skills support across a variety of academic disciplines in the university, as well as students' preferred methods of support, and potential barriers to increasing support within some areas or disciplines.

When tutors were asked what they perceived to be the main barrier(s), if any, to adopting a more proactive approach towards supporting the 
development of students' numeracy skills within their programme(s), many cited: fear of loss of subject time (60\%), lack of trained staff (45\%), staff expectations that students embarking upon programmes already possess the necessary skill competencies (39\%), lack of necessary numeracy skills/mathematical expertise amongst staff (27\%), and perceived lack of the value of numeracy to the subject/discipline (24\%).

When students were asked how they would prefer to further develop and practise their numeracy skills, the top preferences selected by $\geq 30 \%$ of respondents included: the use of computer-based learning (CBL) materials (58\%), small group tutorials or workshops with a lecturer (53\%), working through a textbook (40\%), one-to-one help from a lecturer $(37 \%)$, and workshops or tutorials organised by a central unit (31\%). Peer-assisted learning was selected by $28 \%$ of respondents.

\section{Evidence and recommendations}

Recommendations presented in the project's final report (Tariq, et al., 2010) included:

- highlighting to students across all disciplines the value of mathematics/numeracy skills, particularly in the context of their future employability; raising student and tutor awareness of employers' use of numeracy tests, providing greater access to sample tests and providing workshops and/or drop-in sessions to address any weaknesses identified;

- ensuring that tutors are aware of the level of mathematics anxiety within their student population and its potential to impact upon student performance, particularly amongst mature, female students and those possessing no (or a low standard of) formal pre-university mathematics (or -related) or numeracy qualifications;

- (based upon students' responses) encouraging and supporting the greater adoption of ICT and the use of CBL materials to support the further development of students' numeracy skills and to provide students with more opportunities to practise their skills; also exploring the design and introduction of peer-tutoring schemes.

At the start of the project the university provided no central mathematics or numeracy skills support for its students. However, one outcome of the project has been the establishment of a central drop-in facility, which provides one-hour lunch-time sessions during term-time, facilitated by a member of the original project team. In a trial of the scheme, attending students represented all four faculties: queries from Science and Technology students concerned rearranging equations, laws of motion, differentiation, sine rule, vectors and Laplace transform; Management students sought clarification on questions set, the presentation of coursework and algebra; Health and Social Care students were primarily concerned with converting units of measurement; while prospective teachers in Arts, Humanities and Social Sciences were concerned about how to pass the numeracy test associated with acquiring Qualified Teacher Status (QTS).

It is vital universities ensure that their undergraduate populations are equipped not only with the numeracy skills necessary for progression and success within their academic disciplines (where appropriate), but also with those numeracy skills necessary for them to attain graduate employment and to be effective subsequently in their workplace. However, the findings of this study revealed a general lack of awareness amongst undergraduates and tutors of the importance of numeracy skills to their students' attainment of graduate employment. While higher education certainly has the potential to deliver a wide range of employability skills in its graduates, this requires universities putting employability skills at the forefront of educational provision and developing such skills contextually in order to highlight to students the importance and relevance of these skills and maintain their motivation to develop them; although even the adoption of a contextual approach does not guarantee transference of these skills to the workplace!

\section{References/more information}

Smith, A. (2004) Making Mathematics Count. Report of Professor Adrian Smith's Inquiry into Post-14 Mathematics Education. London: HMSO. Available at: www.mathsinquiry.org.uk/

Tariq, V. N., Durrani, N., Lloyd-Jones, R., Nicholls, D., Timmins, J. G. \& Worthington, C. H. (2010) Every Student Counts: Promoting Numeracy and Enhancing Employability. Preston: University of Central Lancashire, pp. 127. ISBN: 978-1-901922-75-2. Available at: www.uclan.ac.uk/information/services/ Idu/files/ESC_FINAL.pdf 


\section{lb: Business Applications in Mathematics}

\section{Skills Addressed:}

Problem solving • Communication \& interpersonal skills •

Team working • Presentation techniques (oral and written)

\section{Valerie Matthews-Lane (Clive Rix and Richard Mendez)}

Department of Mathematics, University of Leicester

\section{Context}

'Business Applications of Mathematics' is a ten credit optional module which requires second year mathematics students to work on 4 consecutive case studies based on real life business problems. The module gives students the opportunity to experience the application of mathematical theory and mathematical modelling in a business context where problems are often not clearly defined and do not fall into obvious categories. Students reflect on the transferable skills they are developing whilst working through the case studies and are encouraged to consider how they can evidence these in the recruitment and selection process for graduate employment.

\section{Implementation (including barriers and enablers)}

The case studies require students to work in small groups (the groups change for each case study). Students work together to identify and present solutions to a specific business problem. This involves understanding the problem, working out what mathematical technique(s) to utilise and reporting back on the recommended solution (rather than the mathematics of how it was solved). Students present their work in an assessed report and a formal presentation without the use of mathematical jargon. Constructive feedback after each of the case studies ensures that students are able to refine their approach and develop their skills further. In addition to applying their mathematical skills in a business context, students also develop essential employability skills such as oral and written communication, team-working, analytical and problem-solving skills and presentation techniques. During the programme students work on 4 different consecutive case studies, 3 of which are assessed. Brief details of 2 of the case studies are included below for information:

\section{Case Study A:}

The manager of a colliery which produces 20,000 tonnes of coal a week is currently experiencing quality problems. To satisfy his customer, the local power station, he needs to provide coal with a minimum calorific value of 24 gigajoules per tonne $(\mathrm{Gj} / \mathrm{t})$. Current coal preparation techniques only produce coal at $23 \mathrm{Gj} / \mathrm{t}$. Students are given information on the range of options for improving the calorific value of the coal and the costs and implications of doing this. They are required to work in teams to identify the optimal solution and also to look at options for addressing a sudden change in the client's requirements. Teams subsequently present their optimal solutions to the 'class' explaining how they arrived at their solution. 
Individuals also submit their own report on the case study.

\section{Case Study B:}

A new Commercial Director for a small organisation is worried that the procurement system is inefficient. The company maintains inventories of five items. Students are given information including the yearly demand, costs per unit, how frequently they are ordered and associated costs including the cost of each order and carrying costs [warehousing and financing the stock]. The students are asked to review the approach and policy and suggest whether there is a better approach that would save the organisation money. Similar to Case Study A they are required to deal with a change in circumstances related to limitations on working capital at the present time. Reporting requirements are the same as Case Study A - group presentation and individual report.

The module also includes sessions delivered by careers and work-related learning specialists to help students reflect on the skills they are developing throughout the module. These sessions involve students identifying and articulating their skills and considering how these might be transferred to the workplace. They learn how to produce an effective CV and covering letter including how to target their approach and how to provide evidence of their skills. A simulated application exercise exposes them to different CV styles and approaches and requires them to evaluate 3 different $C V s$ in relation to an advertisement for a work experience placement. As part of the assessment process students articulate learning from the module and the skills developed in a formal presentation. They also complete a simulated job application for which they produce a targeted CV and covering letter which are assessed and contribute to the overall mark for the module.

\section{Evidence and recommendations}

The module as it currently stands has gone from strength to strength following an initial pilot in the Spring term of 2009 when around 6 students completed it to an anticipated cohort of 38 students in 2011. The assessment process includes both formative and summative elements. The student is required to apply their skills in practice during the module and receives feedback to enable them to refine their approach. Marks awarded to the different assessment elements combine to produce and overall mark for the module.
In 2009 a short evaluation survey was conducted to gather feedback on the module. The overall response was positive with 2 recommendations for improvement implemented.

\section{References/more information}

Institute of Directors skills briefing, December 2007, 'Graduates' employability skills'

CBI \& Universities UK, March 2009, 'Future fit: Preparing graduates for the world of work'

Mendez, R. \& Rix, C. (2010) A new approach to developing employability skills in mathematics students, Association for Sandwich Education and Training, University of Leicester, 7th-9th September. 


\title{
17: Embedding careers awareness in the first two years of a Mathematics degree
}

\author{
Skills Addressed: \\ Careers awareness $\bullet$ Writing job applications • Compiling CVs
}

\section{David Graham and Annette Millare}

'School of Computing and Mathematics, ${ }^{2}$ Careers and Employability Service, University of Plymouth

\section{Context}

Establishing an employability framework is a key part of the University of Plymouth's strategic plan [1] which is further backed up by its mission which includes a statement on employability [2]. This assures students that their career development is an important part of their education at the University, and promises to provide opportunities for students to develop their employability skills, together with a promise to support this by providing impartial advice and guidance.

The Mathematics degree at the University of Plymouth fully subscribes to this viewpoint. The degree has been designed to develop 'soft' skills throughout the curriculum. However, we have a seam that runs through the degree (one 20-credit module per year) that is particularly tasked with developing presentation and study skills with a view to preparing students for group or individual project modules in the final year. For several years, a substantial section within each of the skills modules in the first and second year modules has been devoted to careers awareness exercises run by the University's Careers and Employability Service [2]. To encourage student participation, these exercises are formally assessed. This is followed up in the final year by a programme of events including a careers fair, external speakers and talks by past graduates.

\section{Implementation (including barriers and enablers)}

Stage 1: A four-week block of the courseworkonly module MAST1401 "Introductory Computing and Modelling for Mathematics and Statistics" is given over to an exercise in which groups of students investigate the potential careers open to mathematicians and statisticians. Each group of students chooses a different occupational area to prepare a presentation about. In the following weeks, they explore the career using a variety of information sources provided by the Careers Service as well as their own research. A Learning Development adviser also delivers a session about giving effective presentations. In the final week of the block, each group gives a short presentation to the remainder of the class on the results of their research. The presentation is formally assessed and contributes $15 \%$ of the module mark.

Stage 2: A three week block of the coursework-only module MAST2401 "Investigations in Mathematics and Statistics" is devoted to an exercise in which students are introduced to the process of applying for work. The Careers Service give lectures on "Have you got what employers want?", "Writing a good CV and application" and "Interviews and Assessment Centres". The students are also given a careers assignment to complete. In the past the assignment 
has consisted of writing a CV and peer-reviewing it in pairs, followed by a reflective exercise and final amendments. Another option involves getting the students to interview someone in the field that they would like to enter and afterwards to write up a case study about their interviewee's career path, day to day job tasks and tips to graduates. This exercise is worth $5 \%$ of the overall module mark.

Barriers: There have been two main sources of difficulties in implementing these arrangements. The first is that, until recently, we have not had suitable core modules in either of Stage 1 or Stage 2 that are taken by all students including those on major/minor combined awards. This has now been addressed in Stage 2 as the module mentioned above is core for all programmes. However, a small number of majorminor students are still unable to take the MAST1401 module (although they will be able to see the results of the research undertaken by the other students). The second barrier is that students do not always consider careers awareness to be a core part of their studies and thus do not put full effort into such exercises. Consequently, we consider that formal assessment of the exercises is essential to ensure a reasonably high level of participation.

Enablers: The participation of the Careers Advisers in these exercises is seen as essential, giving students a name and face to turn to for careers advice when they need it, as well as being in the best position to make students aware of the careers resources available to them. Enthusiasm from the mathematics staff is clearly also essential in making it clear to students that the exercises are core aspects of their lives as university students and are therefore worthy of their attention. This should be complemented by drip-feeding other aspects of careers awareness (e.g. invitations to careers fairs, notification of other careers events, discussions of students' aspirations and options available to them) through the personal tutor system and other means.

\section{Evidence and recommendations}

One of the most positive aspects of these exercises is that every student enrolled on these modules must take part in the finding out about careers, making job applications and writing CV's. Thus all of the students on the maths degrees have to think about careers, even at a stage in their studies where they may not have expected to do so.

As hinted at above, student perception of the careers exercises is mixed. Positive comments have included:
"Helpful to have facts about what people are doing now who left with a maths degree. Also good to develop presentation skills."

"I thought careers information was very helpful. It makes you think about what you want to do with your degree and that module choice at this early stage can help with your chosen career."

"Finding out about different careers i.e. salaries, work hours, jobs you can only do if you have maths."

"It was good to help look at CVs and make us think about job searching."

Negative comments (most which have now been addressed) have included comments about these exercises deflecting attention away from the core business of studying mathematics, or about the timing of the exercises clashing with deadlines from other modules.

The main recommendations have been hinted at above: involvement of academics in the process and liaising with the Careers service are seen as essential.

\section{References/more information}

1. Strategic plan: http://www.plymouth.ac.uk/pages/ view.asp?page $=1236$

2. Employability statement: http://www.plymouth. ac.uk/pages/view.asp?page=34554

3. Careers and Employability Service: http://www.plymouth.ac.uk/services/careers 
Appendix lA classification of Graduate Skills

\section{Work-based learning (WBL) and/or work-related learning (WRL).}

This can include everything from work experience to year-long work placements, as well as simulated work experience. See Appendix 4 for a typology of modes of WBL/WRL.

\section{Reflection and action-planning, including Personal Development Planning (PDP) and work practices.}

Students need to know how they can improve their levels of achievement. They should be able to identify their own strengths and weaknesses, plan a strategy for addressing the latter and report on progress made toward this. A supported system to provide a framework for such a process should be in place.

Students may also benefit from the compilation of a portfolio, which may include a collection of their work, with a commentary, as well as the above. The portfolio may be physical, electronic, or be a combination of both.

3. Career Management Skills (CMS) - likely to involve the University Careers Service.

It is important that students know what career paths are available to them, and have the necessary skills to gain access to them. The key CMS skills required are:

- Knowing how to write a good CV, sourcing job opportunities, researching the company, preparing a good job application, interview types and activities, handling difficult interview questions.

- Reflecting on work experience or placement and recognising their own achievements. Being able to articulate these skills, through oral or written presentations or through a poster.

- Enterprise skills, entrepreneurship, innovation, commercial/sector awareness.

4. Employability skills - recognising that a degree is about more than the subject itself.

Other skills that should be gained include:

- Communication, Team-working, Leadership, Problem solving, Logical argument, IT skills, Numeracy.

The following attributes are also desirable:

- Self-motivation, Self-management, Self-efficacy, Adaptability, Reliability, Leadership skills, Self-articulation. 


\section{- Appendix 2 - Mechanisms and inputs for embedding Graduate Skills}

\begin{tabular}{|c|c|}
\hline $\begin{array}{r}\text { INPUTS } \\
\text { Employers } \\
\text { Academic Tutors } \\
\text { Careers Service } \\
\text { Research } \\
\text { Employability Statements } \\
\text { Self Evaluations } \\
\text { Course reviews } \\
\text { National Student Survey (NSS) } \\
\text { Internal Academic Review } \\
\text { Student Feedback } \\
\text { Student Union } \\
\text { Institutional quality assurance and } \\
\text { enhancement processes } \\
\text { Learning, teaching and assessment } \\
\text { good practice } \\
\text { Student support services } \\
\text { Widening Participation } \\
\text { Diversity }\end{array}$ & $\begin{array}{l}\text { ME CHANISMS } \\
\text { Assessment Practice: } \\
\text { Written presentation } \\
\text { Oral (group/individual) presentation } \\
\text { Highlighting the purpose \& benefit } \\
\text { Learning, teaching and assessment practices } \\
\text { and styles: } \\
\text { Problem-based learning } \\
\text { Enquiry-based learning } \\
\text { Project work } \\
\text { Simulated tasks } \\
\text { Seminar work } \\
\text { Group work } \\
\text { Personal Development Planning: } \\
\text { Reflective practice, organisation } \\
\text { Problem identification } \\
\text { Action planning \& target setting } \\
\text { Encourage self-awareness } \\
\text { Reporting and evaluation } \\
\text { e-Portfolios } \\
\text { Peer-Assisted Learning } \\
\text { Mentoring } \\
\text { Extra-Curricular Work }\end{array}$ \\
\hline
\end{tabular}




\section{- Appendix 3 -
- An Employability 'Thread'}

\begin{tabular}{|c|c|c|}
\hline Year & Activity & Skills \\
\hline \multicolumn{3}{|c|}{ Open day presentation introduces the importance of developing 'graduate' skills } \\
\hline \multirow[t]{8}{*}{1} & Discussion of skills at induction & Skill awareness \\
\hline & Progress file & Reflection, action-planning, target-setting, organisation \\
\hline & Web Portfolios & Communication \\
\hline & CV-production & Self-awareness, career management \\
\hline & $\begin{array}{l}\text { Peer-Assisted Learning, group work, } \\
\text { oral (group) and poster presentations }\end{array}$ & Teamwork, self-efficacy, problem solving, leadership \\
\hline & Essay on study skills & Self awareness, awareness of the 'wider picture' \\
\hline & Employer Mentoring* & Career development/awareness \\
\hline & End of year reflection on skill development & Reflection, self-awareness, recognition of progress \\
\hline \multirow[t]{5}{*}{2} & Progress file & Reflection, action-planning, target-setting, organisation \\
\hline & Web Portfolio & Communication \\
\hline & Venture Matrix & $\begin{array}{l}\text { Work-related learning, communication, } \\
\text { interdisciplinary teamwork, negotiation skills }\end{array}$ \\
\hline & Delivering small group presentations & Communication, teamwork \\
\hline & $\begin{array}{l}\text { Preparation and application for industrial placement: } \\
\text { - CV assessment } \\
\text { - self-appraisal } \\
\text { - employer awareness } \\
\text { - job-application skills } \\
\text { - writing covering letters } \\
\text { - answering difficult questions } \\
\text { - interview skills }\end{array}$ & $\begin{array}{l}\text { Career development, career management skills, } \\
\text { Self-awareness, confidence }\end{array}$ \\
\hline 3 & Industrial placement (optional) & Work-based learning \\
\hline \multirow[t]{5}{*}{4} & Progress file & Reflection, action-planning, target-setting, organisation \\
\hline & Web Portfolio & Communication \\
\hline & $\begin{array}{l}\text { Professional Development module } \\
\text { - industry and career awareness } \\
\text { - self-evaluation and reflection } \\
\text { - group presentation and poster } \\
\text { - individual poster presentation }\end{array}$ & Career development, teamwork, communication \\
\hline & Peer-Assisted Learning (PAL) Leader & Leadership, self management, adaptability \\
\hline & $\begin{array}{l}\text { Individual Project: } \\
\text { - oral presentation } \\
\text { - report } \\
\text { - oral examination }\end{array}$ & Problem solving, adaptability, communication \\
\hline
\end{tabular}

*Employer mentoring is possible at any stage of the course 


\section{- Appendix 4 - A Typology of - Modes of Work-Based Learning}

It is possible to identify a number of modes or approaches to Work-based learning (WBL):

\begin{tabular}{|c|c|c|c|}
\hline Type of WBL & Objectives & Location/context & Duration \\
\hline Sandwich work placement & $\begin{array}{l}\text { Application of knowledge in a } \\
\text { practical context; development of } \\
\text { skills and attributes relevant to a } \\
\text { professional/vocational area. }\end{array}$ & $\begin{array}{l}\text { Company or } \\
\text { organisation. }\end{array}$ & $\begin{array}{l}1-2 \text { semesters up to } \\
\text { a calendar year. }\end{array}$ \\
\hline $\begin{array}{l}\text { Integrated practice } \\
\text { placement where the } \\
\text { student may also be a } \\
\text { trainee or employee. }\end{array}$ & $\begin{array}{l}\text { As above; introduction to } \\
\text { a community of practice; } \\
\text { professional accreditation. }\end{array}$ & $\begin{array}{l}\text { Block placement } \\
\text { in a professional } \\
\text { environment. }\end{array}$ & $\begin{array}{l}\text { Up to } 50 \% \text { of } \\
\text { programme, often } \\
\text { divided into blocks. }\end{array}$ \\
\hline $\begin{array}{l}\text { Employment-based learning } \\
\text { programme e.g. sector } \\
\text { focused foundation degree. }\end{array}$ & $\begin{array}{l}\text { Sector recognised } \\
\text { vocational qualification. }\end{array}$ & $\begin{array}{l}\text { Company or } \\
\text { organisation. }\end{array}$ & $\begin{array}{l}\text { In a work } \\
\text { environment for most } \\
\text { of the programme. }\end{array}$ \\
\hline $\begin{array}{l}\text { Assessment/accreditation } \\
\text { of learning from work } \\
\text { outside university e.g. part } \\
\text { time employment. }\end{array}$ & $\begin{array}{l}\text { Integration of theoretical and } \\
\text { practical knowledge; reflection } \\
\text { on development of skills } \\
\text { and attributes relevant to a } \\
\text { professional/vocational area. }\end{array}$ & $\begin{array}{l}\text { Company or } \\
\text { organisation. }\end{array}$ & $\begin{array}{l}\text { Can be short term } \\
\text { (a few days) up to a } \\
\text { semester or a full year. }\end{array}$ \\
\hline $\begin{array}{l}\text { Project with a } \\
\text { commissioning organisation. }\end{array}$ & $\begin{array}{l}\text { Application of knowledge in a } \\
\text { practical context; project and client } \\
\text { management skills. }\end{array}$ & $\begin{array}{l}\text { Company or } \\
\text { organisation. }\end{array}$ & $\begin{array}{l}\text { Can be short term } \\
\text { (a few days) up to } \\
\text { a semester. }\end{array}$ \\
\hline $\begin{array}{l}\text { University } \\
\text { Employability Award }\end{array}$ & $\begin{array}{l}\text { Development of employability } \\
\text { skills, in particular "soft skills". }\end{array}$ & $\begin{array}{l}\text { Voluntary } \\
\text { organisation. }\end{array}$ & $\begin{array}{l}\text { Can be short term } \\
\text { (a few days) up to } \\
\text { a semester. }\end{array}$ \\
\hline $\begin{array}{l}\text { Sheffield Hallam University } \\
\text { Venture Matrix (VM) }\end{array}$ & $\begin{array}{l}\text { Application of knowledge in a } \\
\text { practical context; project and client } \\
\text { management skills. }\end{array}$ & $\begin{array}{l}\text { VM organisations } \\
\text { or external } \\
\text { company/ } \\
\text { organisation. }\end{array}$ & One semester \\
\hline $\begin{array}{l}\text { Residential/ block week } \\
\text { activities with outside } \\
\text { clients/ organisations }\end{array}$ & $\begin{array}{l}\text { Application of knowledge in a } \\
\text { practical context; project and client } \\
\text { management skills; working under } \\
\text { pressure to a professional standard. }\end{array}$ & $\begin{array}{l}\text { Company or } \\
\text { organisation. }\end{array}$ & Usually several days. \\
\hline $\begin{array}{l}\text { Student } \\
\text { Ambassador Scheme }\end{array}$ & $\begin{array}{l}\text { Development of personal and } \\
\text { interpersonal employability skills. }\end{array}$ & University & $\begin{array}{l}\text { Open days etc. } \\
\text { as required. }\end{array}$ \\
\hline
\end{tabular}

Table based on De Montfort University (2006) "Work-based learning handbook", p4, produced by Department of Academic Quality and Student Support Services. 
Developing Graduate Skills in HE Mathematics Programmes - Case Studies of Successful Practice 


\section{References}

1. 'Higher Ambitions: The Future of Universities in a Knowledge Economy', (November 2009), http://webarchive.nationalarchives.gov.uk/tna/+/http://www.bis.gov.uk/wp-content/uploads/publications/ Higher-Ambitions.pdf/, last accessed 02/09/10.

2. 'Unleashing Aspiration: The Final Report of the Panel on Fair Access to the Professions', January 2010, http://www.cabinetoffice.gov.uk/media/227102/fair-access.pdf, last accessed 02/09/10.

3. 'National Student Forum Annual Report' (October 2009), http://www.nationalstudentforum.com/wordpress/ wp-content/uploads/2009/10/NSF_annual_report_2009.pdf, last accessed 02/09/10.

4. 'Talent, Opportunity, Prosperity - A Manifesto for Graduate Recruitment', Association of Graduate Recruiters (March 2010), http://www.agr.org.uk/Content/AGR-A-manifesto-for-graduate-recruitment , last accessed 02/09/10.

5. 'One Step Beyond: Making the Most of Postgraduate Education'. BIS (March 2010), http://www.bis.gov.uk/one-step-beyond, last accessed 02/09/10.

6. ' Maths at University' (2010), More Maths Grads project, http://www.mathscareers.org.uk/_db/_documents/MathsatUniversity.pdf, last accessed 02/09/10

7. 'Employability - Incentivising Improvement', UKCES, June 2010, http://www.ukces.org.uk/upload/pdf/424704_UKCES_Employability_AW_2.pdf, last accessed 02/09/10.

8. 'Employability Statements - HEFCE Letter to Universities', http://www.hefce.ac.uk/pubs/circlets/2010/cl12_10/, (June 10, 2010), last accessed 02/09/10.

9. David Willetts, House of Commons Debates, 8 July 2010, http://www.theyworkforyou.com/debates/?id=2010-07-08a.511.1

10. 'University Challenge', Keynote speech on HE, David Willetts, 10 June 2010, http://www.bis.gov.uk/news/topstories/2010/Jun/challenges-for-he, last accessed 02/09/10.

11. Subject Benchmark statement for Mathematics, Statistics and Operational Research, QAA, December 2007 , http://www.qaa.ac.uk/academicinfrastructure/benchmark/statements/Maths07.pdf

12. Samuels, P., and Williams, G (2010), 'Developing students' self-efficacy through mathematical study skills resources', MSOR Connections Vol 10 No .2.

13. Kane, S., and Sinka, I (2009), 'Good practice in undergraduate peer support', MSOR Connections Vol 9 No 4.

14. Challis, N., Robinson, M. and Thomlinson, M (2009), 'Employability skills in mathematical courses', MSOR Connections Vol 9 No 3.

15. Hibberd, S., Grove, M. et. al. (2009), 'Developing graduate and employability skills within a mathematical sciences programme', MSOR Connections Vol 9 No 2.

16. Tariq, V., and Durrani, N. (2009), 'Every Student Counts: Promoting Numeracy and Enhancing Employability', MSOR Connections Vol 9 No 1. 
Developing Graduate Skills in HE Mathematics Programmes - Case Studies of Successful Practice 

There are significant barriers involved when seeking to modify Mathematics programmes to encourage the development of graduate skills. One barrier is the practical difficulty of finding space for graduate skill development in a crowded curriculum. This can be addressed, at least in part, through different approaches toward learning, teaching and assessment that allow skill development to take place alongside the development of the mathematical skills, and by encouraging students to take part in extra-curricular activities.

A series of short case studies have been collected, each focused on specific graduate skills, providing examples of ways in which these have been successfully developed through curricular initiatives. There is a wide variety of work reported, both in terms of the skills developed as well as the type of courses and institutions involved. The hope and expectation is, therefore, that there will be something of interest and relevance to everyone who has a desire to make curricular changes aimed at improving the 'graduate' skill levels of their students.

This work was funded by the Mathematical Sciences HE Curriculum Innovation Project, operated by the Maths, Stats and OR (MSOR) Network as part of the Mathematical Sciences Strand of the National HE STEM Programme. Find out more at www.mathstore.ac.uk/hestem 